OPEN ACCESS

Edited by:

Luis Huckstadt,

University of California, Santa Cruz,

United States

Reviewed by:

Shinya Kouketsu,

Japan Agency for Marine-Earth

Science and Technology (JAMSTEC),

Japan

Rosalino Fuenzalida

Arturo Prat University, Chile

${ }^{*}$ Correspondence:

Marcos V. B. Silva

marcosilva.oc@gmail.com

Specialty section:

This article was submitted to

Ocean Observation,

a section of the journal

Frontiers in Marine Science

Received: 24 August 2021 Accepted: 27 October 2021 Published: 08 December 2021

Citation:

Silva MVB and Araújo TCM (2021)

The South American Advances

in Submarine Canyons Studies

and Their Link to the Ocean Decade.

Front. Mar. Sci. 8:764029.

doi: 10.3389/fmars.2021.764029

\section{The South American Advances in Submarine Canyons Studies and Their Link to the Ocean Decade}

\author{
Marcos V. B. Silva* and Tereza C. M. Araújo \\ Geological Oceanography Laboratory, Department of Oceanography, Recife, Brazil
}

Submarine canyons have a relevant role in marine ecosystems. They are responsible for oceanographic conditions such as variability of temperature and salinity, sediment transport, nutrients, and even pollutants amongst marine areas. Submarine canyon studies have been growing and reaching prominence due to their importance in the Blue Economy. Initiatives to promote sustainable development for the ocean have been discussed in the Ocean Decade. Although canyons studies are increasing, how can we integrate these with the Ocean Decade outcomes? Thus, we aim to demonstrate an overview of the advances of submarine canyons studies and their link to the Ocean Decade for South America. We analyzed 160 studies divided into spatiotemporal analysis and study approaches according to the Ocean Decade outcomes. We discuss these articles, building a timeline and argumentative topics considering the advances, and discuss gaps to predict the future of submarine canyons studies in the Ocean Decade and Blue Economy context.

Keywords: Ocean Decade, continental margin, seabed, marine events, spatiotemporal analysis

\section{INTRODUCTION}

Submarine canyons are relevant marine features that make up continental margins around the world. They are biodiversity hotspots responsible for marine environment health (Santora et al., 2018; Robertson et al., 2020). Currently, several studies have been published about submarine canyons and their influence on the ocean and how a seabed feature is essential to provide a complex system amongst the geological (Fildani, 2017), physical (Aguiar et al., 2018), biological (Bernardino et al., 2019), and social (Uddin et al., 2021) processes. Submarine canyons studies aim to understand the association of each process that belongs to their system, increasing the overview on different study subjects as well as the specific locals present on continental margins, shelf-break, slope, or close to the rise areas in the ocean (Leynaud and Sultan, 2010; Callow et al., 2014; Lavagnino et al., 2020).

Several studies have been published and involve different approaches on submarine canyons. For instance, some studies have aimed to assess the impacts of pollution (Cau et al., 2017; Kane and Clare, 2019). Other approaches are understudied and need to be developed, i.e., marine geohazards (Meleddu et al., 2016) and geohabitats (Ternes et al., 2020). These studies are even understudied in developed countries, including countries in South America (SA). So, the need to improve the knowledge about submarine canyons in these areas is clear, especially about their oceanographic processes and impacts. 
The lack of funding to scientific studies in SA has negative impacts in all spheres of a country, mainly in their economy. The Blue Economy concept is a popular term in ocean governance, which seeks to associate ocean-based development opportunities with environmental stewardship and protection (Voyer et al., 2018). Although its concept is complex and broad, we must highlight its importance following its objectives and feasibility in a balanced and coherent way amongst the countries (SmithGodfrey, 2016). However, it is a challenge due to concept variations and ways of applying the Blue Economy, and their association with the gaps in distribution of the spatiotemporal database of canyons studies in SA, especially in EEZs boundary. Canyon studies examine how countries explore their EEZs, and management of marine space is a matter of national and international importance due to conventions for oceanic areas established by the United Nations Convention on the Law of the Sea (UNCLOS) (Polejack, 2021).

Marine spatial planning (MSP) has developed as a mechanism to cope with the challenges that come along with the allocation of human activities and ecological functions to marine space (Steenbeek et al., 2020). The main purpose of MSP is to promote sustainable development, to identify the use of maritime space, and to manage spatial uses and conflicts in marine areas (European Union, 2014). The MSP concept has been designed to help with decision makers and stakeholders, the disclosure of knowledge, and management of the maritime Blue Economy and marine environment. However, management of marine space is a hard task and needs to be prepared in a systematic and organized way (Mayer et al., 2013). According to the authors, marine ecosystems have been affected by human activities such as fisheries, shipping, wind farms, recreation, and tourism. Thus, it is becoming crucial to regulate and plan marine spatial claims.

Therefore, we understand how canyon studies are important for management MSP and marine ecosystems as fundamentals to society. However, there are several questions to consider. What direction have submarine canyons studies taken over the years? How are they included in marine research? What are the next steps in canyon submarine studies? These are some questions about the future in this research area, and they can drive future studies to contribute to MSP and Ocean Decade Outcomes. The United Nations Decade of Ocean Science for Sustainable Development or Ocean Decade (2021-2030) emerged as an initiative to catalyze transformative ocean science solutions for sustainable development, connecting people, science, and technology to the ocean. The Ocean Decade is a great opportunity to change and support a sustainable development and galvanize ocean sciences for the future (Ryabinin et al., 2019).

The Ocean Decade aims to promote the generation of data, information, and knowledge to move from the 'ocean we have' to the 'ocean we want' through seven outcomes which describe the 'ocean we want' at the end of the Ocean Decade Challenges: (1) A clean ocean where sources of pollution are identified and reduced or removed; (2) A healthy and resilient ocean where marine ecosystems are understood, protected, restored, and managed; (3) A predicted ocean where society understands and can respond to changing ocean conditions; (4) A safe ocean where life and livelihoods are protected from ocean-related hazards;
(5) A sustainably harvested and productive ocean supporting sustainable food supply and a sustainable ocean economy; (6) A transparent and accessible ocean with open and equitable access to data, information and technology, and innovation; and (7) An inspiring and engaging ocean where society understands and values the ocean in relation to human wellbeing and sustainable development (IOC-UNESCO, 2021).

Thus, this study aims to demonstrate an overview for the future of the role of SA submarine canyons studies and their link to the Ocean Decade, highlighting the advances, gaps, and forecasting of them into the marine science development. It also aims to approach their evolution for timeline building and its influence on the world scenario through spatiotemporal analysis.

\section{METHODS}

\section{Database Formation}

The Web of Science and Scopus were chosen to collect papers peer-reviewed in May 2020, which used the same set of keywords, and unlike most reviews, a filter for searching keywords was applied in the whole document to classify the canyons studies in a timeline even if it occurred as just a citation in all of them. Boolean operators were also chosen by the criterium of increase on the searching range. From that: $A L L=$ ("submarine canyon*" OR canyon*) AND (Argentina OR Bolivia OR Brazil OR Chile OR Colombia OR Ecuador OR Guyana OR Paraguay OR Peru OR Suriname $O R$ Uruguay $O R$ Venezuela). In total, 468 studies were retrieved and analyzed for description of main results, but 308 papers were eliminated as they did not match the adopted criteria, such as paleocanyons or continental canyons (Lima and Dias, 2008; Mansurbeg et al., 2012). Finally, 160 studies were selected to compose the database divided into spatiotemporal analysis and types of studies.

\section{Timeline Building}

Three layers of analysis were assumed for timeline building, established by the results of the main aspects (temporal, spatial,

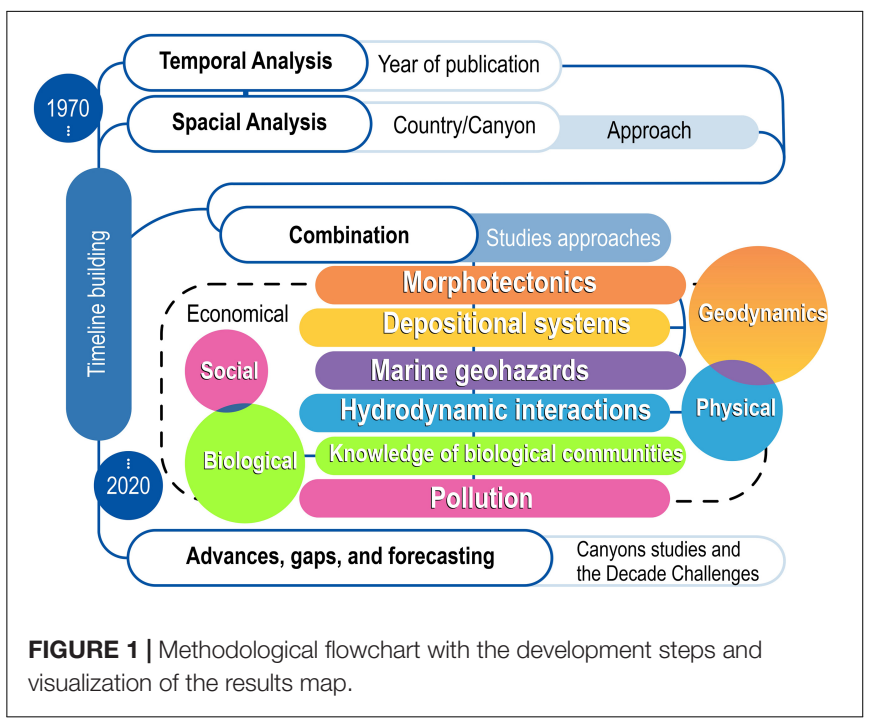


and combination) and one layer related to the advances, gaps, and forecasts of canyons studies and their link with the Ocean Decade (Figure 1).

To check the chronology of studies, the temporal analysis was chosen. Thus, a Productivity Coefficient $\left(P_{c}\right)$ was created, which is equal to the Analyzed Period $\left(A_{p}\right)$ divided by the Number of Publications per Year (NUPPY). From this, we were able to estimate the percentage yield obtained by the difference of the $P_{c}$ values concerning the previous year.

$$
P_{c}=\frac{A_{p}}{N U P P Y}
$$

On the other hand, the spatial analysis considers the distribution of studies among countries, identifying which agents are involved and what approach the studies have. Thus, we decided to rank the countries that publish the most in SA in ascending order, classifying them into three different approaches according to the development stages involving canyons studies, classified in identify (ID), qualify (QL), or quali-quantify (QLQT). The ID occurs when there is a citation of the submarine canyon feature "not directly" related to the study, i.e., when there is a reference to it in the text body without necessarily contributing to the development of the study, ignoring the submarine canyons in a discursive context. The QL occurs when the submarine canyons "characteristics" have contributed to the study development, complemented by a set of arguments observed in the main results, discussion, and conclusions, qualifying the importance of the canyon. At last, QLQT happens when the "characteristics" and "number" of canyons have also corroborated for its development, i.e., besides QL, the cataloging of them is indispensable for the discussion and complement in general.

In combination, we establish the connection with the studies approach, which is defined by their main characteristics. In total, six different study approaches have been identified, divided into four general groups, namely geodynamics (morphotectonics, depositional systems, and marine geohazards), physical (hydrodynamic interactions), biological (knowledge of biological communities), and social appeal (pollution), although each of them has a social character.

Finally, we have discussed the advances, gaps, and forecasting of knowledge of the evolution process involving submarine canyons studies in SA, highlighting the similarities with the Ocean Decade social outcomes.

\section{CHRONOLOGICAL PROGRESS IN SOUTH AMERICA}

Initially, 160 studies were verified for temporal analysis which presents two periods with different characteristics (Figure 2). The first is from 1970 to 2000 and it was verified that its publications did not have a successive periodicity (as an exception in 1994 to 1995 ) but has 10 years between publication intervals (seen in 1983 to 1993). The second period is from 2001 to the present, with a gradual increase in the NUPPY, in addition to maintaining the periodicity over the years. Here, we also observe the relative growth point of studies that separate both periods if we consider the average of the NUPPY.

The individual analysis shows for the first period that the NUPPY has a minimum of one publication per year (for most years until the year 2000) and a maximum of four in 1997. The average of studies over the years began with two studies in 1970, remained relatively stable with one publication per year (except in 1995 by two publications) in the following years until 1997, where four publications were verified, falling again to two and one studies, respectively, in 1998 and 2000.

After the 2000s, a gradual and significant increase in the NUPPY was identified. From 2001 to 2005, 14 studies were published with a $P_{c}$ equal to 2.8 . As a comparison, when analyzing the period from 1970 to 2000 , we 18 studies re published in 30 years with a $P_{c}$ of 0.6 . This shows a $220 \%$ increase in $P_{c}$ in comparison to the first period. Also, from 2006 to 2010 and 2011 to 2015 , productivity increased and remained relatively constant, because even with the respective increase in the $P_{c}$ of 5.4 and 8.0, the values in yield remained at $260.0 \%$. Comparing the period 2016-2020 (61 studies) with the previous (40 studies), we have an increase in both $P_{c}$ of 12.2 and in the yield, reaching $420.0 \%$.

In spatial analysis, the studies number among SA countries shows a difference between the two groups, separated by the criterion of extremes concerning the amount of publication by country. Also, the numbers point to diversity in the type of approach associated with submarine canyons studies for each country as ID, QL, or QLQT.

Moreover, Figure 3 has two groups that stand out concerning the NUPPY. The type of approach is important for maintaining these numbers, especially when analyzing within Group 1 the studies that only mentioned canyons using the ID approach, reaching 32.8\% in Chile with almost 20 studies published and in Group 2 Trinidad and Tobago with a 100\% ID approach for only two published studies. It seems low in comparison QL and QLQT, but we must consider that the composition of each approach is fundamental when analyzing the spatial profiles of studies. Thus, making a relationship between Figure 3 and Figure 4, Brazil, Venezuela, and Guyana are three of the five countries mostly with a QL approach, at the beginning phase, while Argentina and Chile have a QLQT approach in the current phase. The largest numbers of publications with an ID approach are interspersed throughout the interval phase.

\section{TYPE OF STUDIES AND ITS SPATIAL DISTRIBUTION}

Submarine canyons studies were classified according to the main types: (1) morphotectonics, (2) depositional systems, (3) marine geohazards, (4) hydrodynamic interactions, (5) knowledge of biological communities, and (6) pollution. The spatial distribution model was used to find patterns and similarities in a systematic way and more effective responses to advance discussion on submarine canyons studies.

South America shows a spatial distribution pattern, especially when we assign the margin as an analysis parameter. There are differences between the studies carried out on the active 


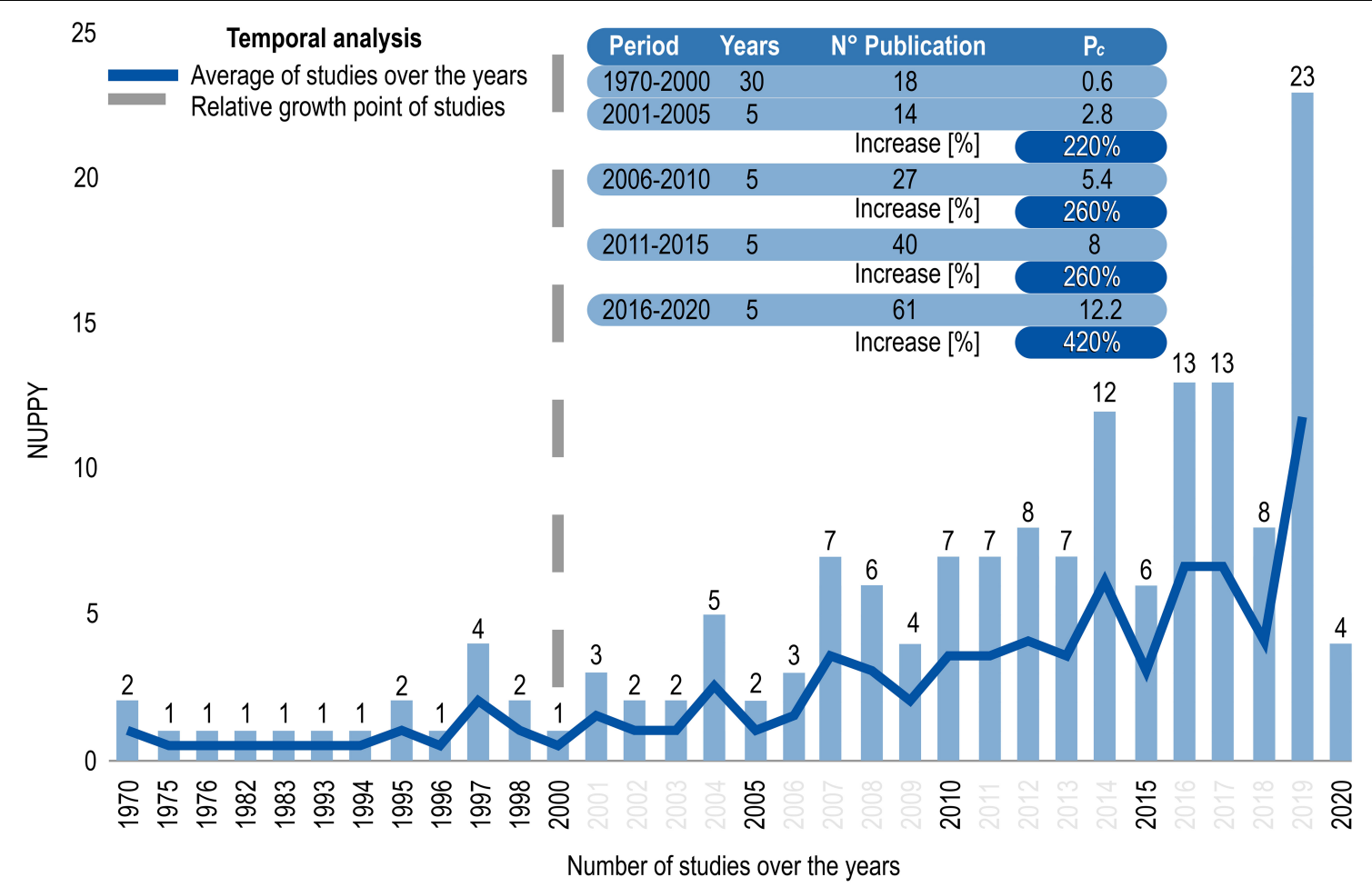

FIGURE 2 | Temporal analysis of submarine canyons studies from 1970 until April 2020 (unfinished), with an average number of studies over the years (dark blue line), and relative growth point of studies (dash gray line). The highlight for the increase of productivity coefficient $\left(P_{C}\right)$ is equal to the period analyzed divided by the NUPPY.

margin as marine geohazards and those on the passive margin as coastal erosion (Figure 5), and the analysis topics with the biggest differences were realized in each study approach. The Supplementary Data Sheet 1 shows the quantity of studies that were chosen to represent the arise point of countries and their first studies' approach over the timeline (as seen in Figure 4).

\section{Morphotectonics}

Morphotectonic studies have been made in the whole timeline relative to three different natures: geomorphological characterization, geomorphological evolution, and tectonic control. At first, the access for turbidites through seismic profiles investigation was performed to map the Demerara and Barracuda abyssal plain through the local bathymetry and morphological characteristics of submarine canyons (Embley et al., 1970; Figure 5B). Geophysical methods and sedimentary framework were used to recognize the geologic history of the southern Brazil-Uruguay continental margin (Butler, 1970). A high influx of sediment from Brazil was dispersed predominantly southeastward along the trend of the Fernando de Noronha Basin, to form the prominent lower Miocene acoustic reflector which occurs throughout the Equatorial Mid-Ocean Canyon (Damuth and Gorini, 1976; Figure 5R).

Generally, morphotectonics studies are based on the identification of seabed features describing their morphological aspects. The acoustic intensity data (side-scan) to describe the morphology of the San Antonio submarine canyon was presented by Hagen et al. (1996), while Alfaro and $\operatorname{Holz}$ (2014), have detailed characterization of the geomorphological architecture of gravity-driven deposits on the tectonically active Caribbean margin and its interpretation of the triggering mechanism of gravity-driven sedimentary processes (Alfaro and Holz, 2014). Almeida et al. (2015; Figure 5S), have provided the first full data coverage of the seafloor between the upper and middle continental slopes $(100-1300 \mathrm{~m})$ adjacent to the Brazilian equatorial margin, using multibeam bathymetric data.

Geomorphological studies are used to classify the features as depressions, channels, pinnacles, and submerged reefs, and their association with seafloor sediment distribution and composition, as well as biological communities' interactions. Studies have discussed the influence of antecedent geology and distinct spatially and temporally driven processes in the formation of the shelf-upper slope depositional features in contrasting geomorphological and sedimentological shelf breaks (D'Agostini et al., 2019; Figure 5N). Also, these studies map the seafloor and geology in the near subsurface using 3-D seismic reflection data from four sedimentary basins, with specific interest in the identification of constructive and destructive surfaces that record the seafloor of these fore-arc basins (Calvès et al., 2017; Figure 5H).

Seabed features like submarine canyons are an important evolution approach that can report on the major tectonic studies in subduction zones, describing the origin of basins based on tectonic control (Schubert, 1982; Figure 5E). They 


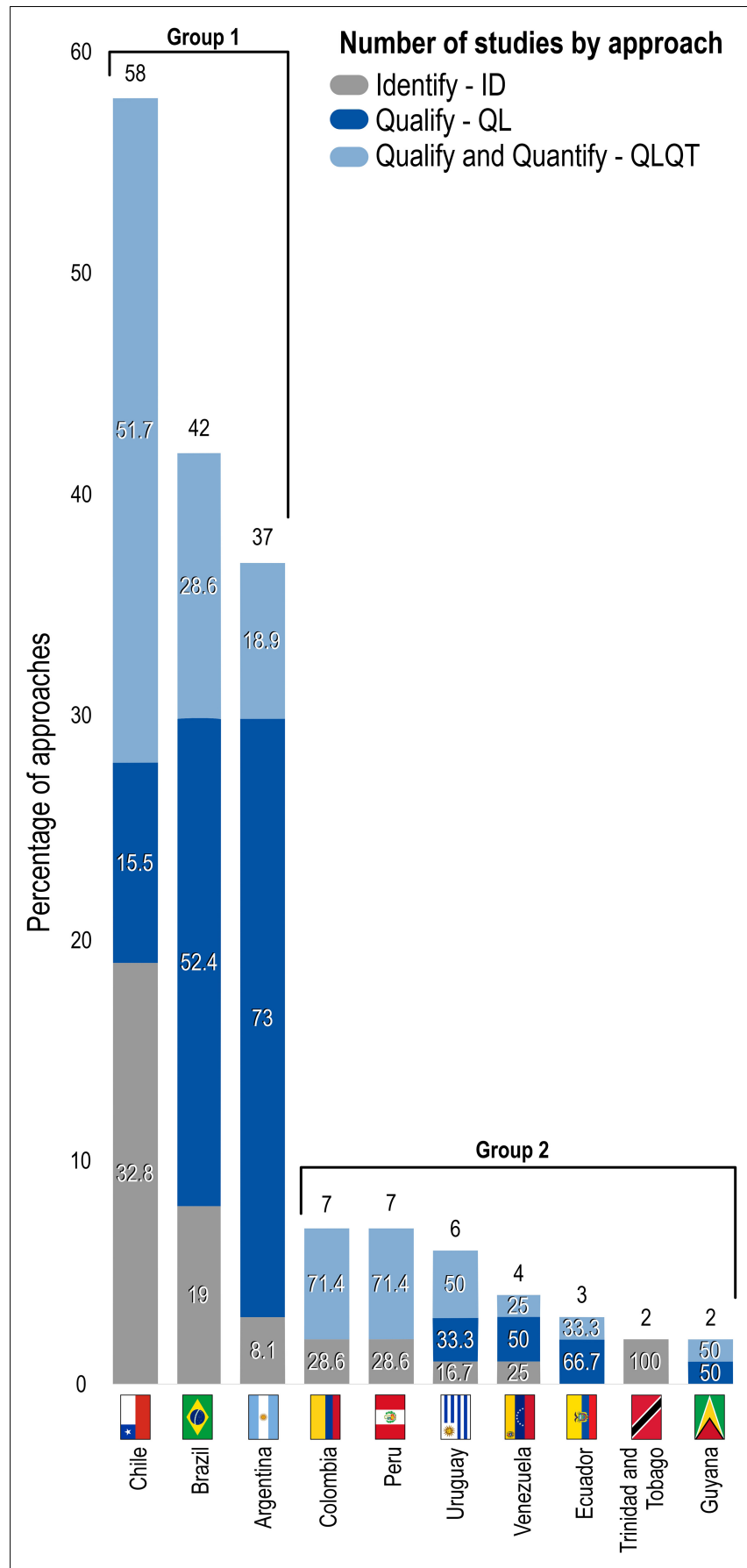

FIGURE 3 | Spatial analysis of submarine canyons studies with emphasis on the percentage of approach types concerning the ranking of publication by country and their division by groups.

can be used to observe the origin and structural evolution of the Valparaiso Basin, which is the only morphologically prominent and structurally significant deep water forearc basin (Laursen et al., 2002), or study the morphotectonics in the forearc region, and their tectonic effect over the subducting Nazca Plate structure on the continental margin (Li, 1995).
Geomorphology and geological controls that led to the incision of the La Aguja submarine canyon are discussed by RestrepoCorrea and Ojeda (2010; Figure 5F), providing strong geologic and geophysical evidence of the major processes that sculpted the canyon: faulting, submarine erosion and axial incision, structural uplift, tectonic subsidence, and mud diapirism.

Seismic investigations to understand the sediment distribution was increased simultaneously to the new methods used. Studies focused on the plate boundary subduction contact, and the tectonic-sedimentary evolution provides a powerful tool to reconstruct exhumation histories of the source areas (Contardo et al., 2008, 2011; Jegou et al., 2008). In the South-Central Chilean margin, for example, the reconstruction of the relevant processes is applied to sediment pathways that can be reconstructed based on longitudinally variable topographic and orographic settings (Heberer et al., 2011; Figure 5K).

Studies involving climate changes were also developed concerning the variability of temperature and their impacts on the sea. Armijo et al. (2015) hypothesize that a global plate tectonic reorganization involving long-lasting viscous mantle flow has probably forced both Andean orogeny and global climate cooling since $~ 50$ Ma. Michaud et al. (2015; Figure 5G) evaluate the spatial and temporal contribution of tectonic and climate changes on the structural development and stratigraphic evolution of the Ecuador continental margin. Quaternary studies have progressed in continental margin zones and have been associated with geomorphological evolution studies such as sea level rising and the last glacial lowstand (Camargo et al., 2015). Shelf-margin studies to reconstruct late quaternary sedimentary and advance new insights into the age as well the hydrocarbons deposits under the seafloor are being developed (Ercilla et al., 2019; Mason et al., 2019).

Also, mass transport complexes (MTCs) studies emerge as important deposits transported by submarine canyons. The MTC in deep-water basins means that efficient oil and gas exploration and development in such settings hinge on an understanding of the nature, processes of formation, distribution, and relationship between them. Deposits share with surrounding deep-water environments, and also pursue a detailed geomorphological study of the last glacial lowstand shelf-margin system along eastern offshore Trinidad (Moscardelli and Wood, 2008; Moscardelli et al., 2012; Figure 5C). Besides, recent mass-transport deposits (MTDs) in the Ecuador trench are identified, and their volumes and sources are estimated, discussing their potential causes by comparing their frequency with the sea-level rise over the last $23 \mathrm{kyr}$, turbidites frequency over $\sim 5 \mathrm{kyr}$, and local earthquakes frequency during the last century (Ratzov et al., 2010; Figure 5F).

The evolution of methods and ways to collect data as well as the objective (2) of Ocean Decade, morphotectonics studies are fundamental to survey research to generate comprehensive knowledge and understanding of the ocean floor. Several morphotectonics studies have used advanced survey mapping technology to investigate the seabed (Jara-Muñoz et al., 2017), substrate (Gruetzner et al., 2016), sediment layers (Esteban et al., 2017), bedforms (Gomes et al., 2016; Figure 5T), and flowtopography interaction (Warratz et al., 2019), but almost all describe in detail the marine morphology and its depositional 


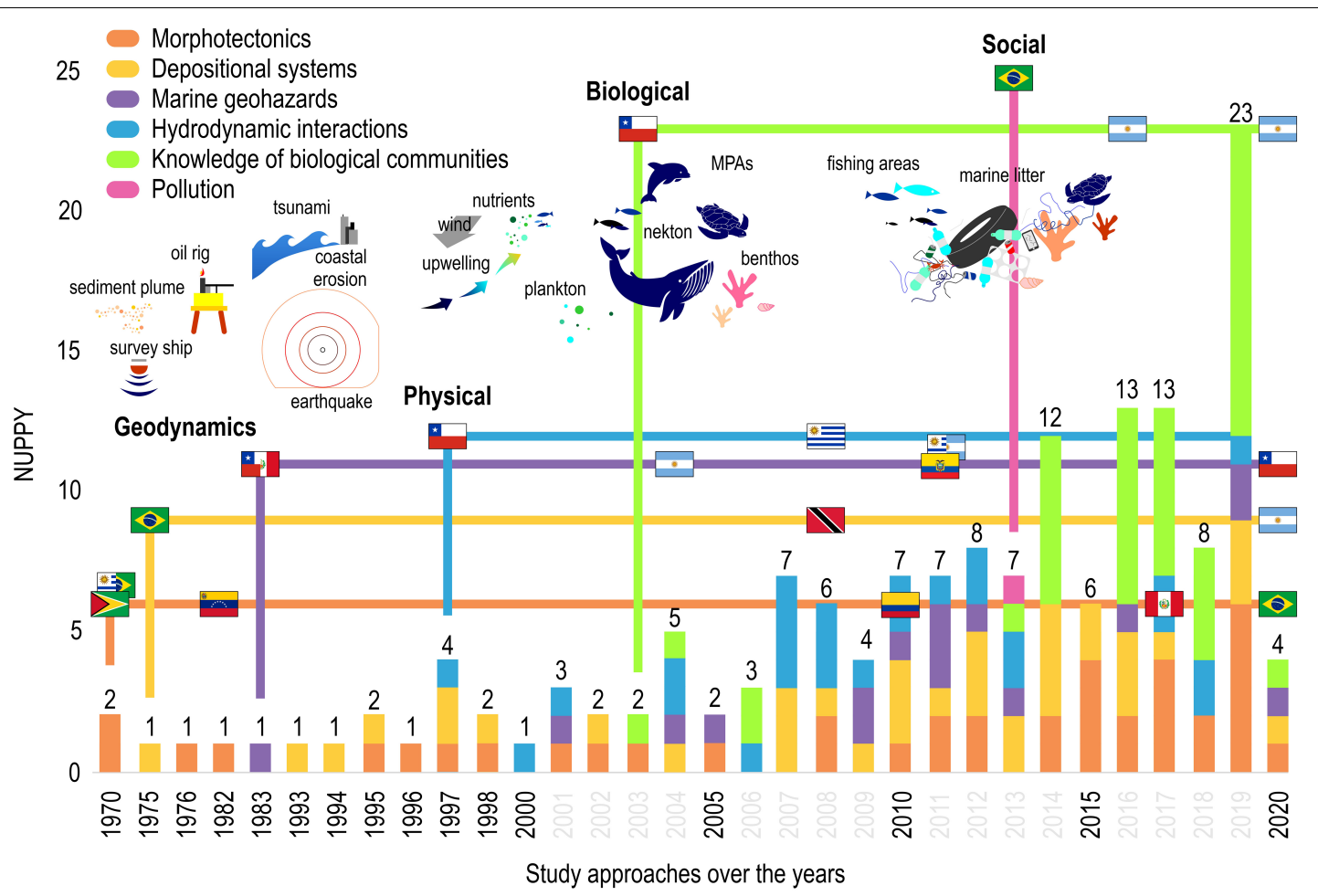

FIGURE 4 | Timeline evolution of submarine canyons studies in South America, highlighting the changes in the specificity of study trends (geodynamics, physical, biological, and social) and their main publication agents to represent the arise point of Number of Publication per Year (NUPPY) among the countries and their first specificities of studies over the timeline.

architecture (do Nascimento Silva et al., 2018; Idárraga-García and León, 2019; Lavagnino et al., 2020).

\section{Depositional Systems}

Depositional systems studies were carried out to understand the sedimentary processes in the marine environment, reporting how seabed features are formed. Depositional systems studies are divided into four categories: sediment dynamics, stratigraphic architecture, hydrocarbons, and chronostratigraphic. From sediment dynamics, studies of seabed mapping were the first found to evaluate sedimentary processes as a link with the previous specificity (morphotectonics). Damuth (1975; Figure 5A), have demonstrated how echograms can be utilized in conjunction with sediment data (piston cores, etc.) to evaluate sedimentary processes to best describe the morphological features mapping. Several methods were used to map a huge extension of the seafloor over the EEZ's of SA countries as side-scan sonar, single-channel seismic reflection, and bottom sampling survey across the Peru-Chile forearc mapped a large submarine canyon system offshore of southern Peru and northern Chile (Hagen et al., 1994).

Depositional studies are generally focused on understanding sedimentary mass transport (Gruetzner et al., 2012; Lorenzoni et al., 2012) through submarine canyons between continental shelves and abyssal plains, and understanding the characteristics of the sandy turbidites deposited on an active margin, which reveals their characteristics and patterns of Quaternary sandy deposits distributed across the entire Venezuelan margin (Faugères et al., 1993; Figure 5C). These studies describe the sedimentary processes that occur near canyons as features formation (Bruhn and Walker, 1995), the sand bodies geometry (Bruhn and Walker, 1997; Hübscher et al., 2002), grain-size distribution (Heberer et al., 2010), submarine canyon as a conductor of sediments and nutrients (Bernhardt et al., 2015, 2016), and the characteristics of organic matter present in bulk surface sediments (Escobar et al., 2019; Figure 5Q).

On the other hand, depositional systems studies have already deeply explored the flow-topography interaction (FrancoFraguas et al., 2014) to analyze the imprint over the modern sediments of the local oceanographic phenomena and the complex interplay between different geostrophic currents and hydrological processes from the outer shelf to offshore (Viana et al., 1998; Figure 5N). According to Lima et al. (2007), the objective is to develop a tool to simulate the interaction between bottom currents and the submarine physiography, and to depict the relative importance of any individual currentforcing mechanism as a sediment-reworking agent.

Depositional systems studies also are following new estimates of age using geochemistry data sets to improve sedimentary evolution knowledge (Muñoz et al., 2004, 2007; Violante et al., 2010) and using chronostratigraphic analysis to understand and reconstruct the previous coastal environment. These studies aim to understand how the events of long-term exposure and limited subsidence have controlled the characteristics of the Holocene 


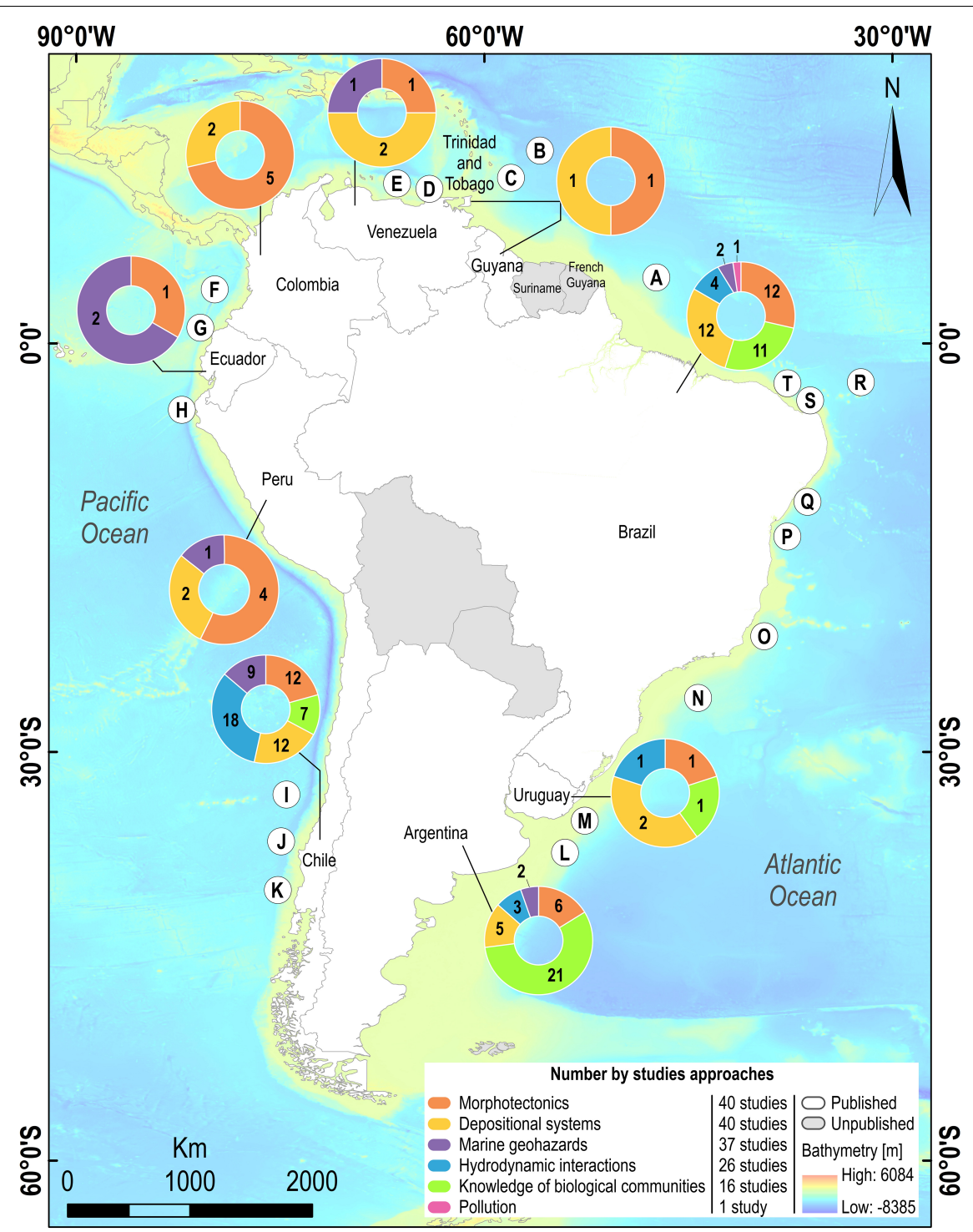

FIGURE 5 | Spatial distribution map of studies on submarine canyons areas (letters) in South America with emphasis on the number of publications by different specificities data with countries in white that have published and in gray that did not publish. (A) Amazon. (B) Vidal Deep-Sea. (C) Darien Ridge. (D) Manzanares. (E) Los Roques. (F) Patia/Mira/Esmeraldas/La Aguja. (G) Santa Helena/Guayaquil. (H) Paita/La Bocana. (I) San Antonio/Rapel/Mataquito/Maule/Itata. (J) Biobio/Lleulleu/Imperial/Toltén/Lingue. (K) Callecalle/Chaihuin/Chacao/Cucao. (L) Mar Del Plata/Ameghino. (M) Ignacio. (N) Almirante Câmara/Grussai/Rio Doce/Watu Norte/São Tomé. (O) Regencia. (P) Salvador/Itacaré/Almada/Uma/Canavieiras. (Q) São Francisco/Japaratuba. (R) Equatorial Mid-Ocean/Fernanado de Noronha Arquipélago. (S) Grossos/Areia Branca/Mossoró/Apodi/Ponta do Mel. (T) Ponta do Mangue/Macau/Assu.

sedimentation, the distribution of the seascapes and the human uses management, particularly for the fishery areas (Dominguez et al., 2013; Figure 5P). They also aim to study the dominant sedimentary processes (outer-shelf hydrodynamic, effects, crossshelf export mechanisms, bottom-current, transport) which are discussed based on seism-acoustic profiles, lithological texture, grain-size distribution, and terrigenous Neodymium isotopic data (Hanebuth et al., 2019; Figure 5M). Chronological studies were developed to investigate the temporal evolution of geological structures (Riedinger et al., 2017; Collot et al., 2019).

Stratigraphic architectures studies appeared to characterize the architecture of substrate, highlighting their sedimentary and morphological processes (Vergara, 1997; Berton and Vesely, 2016). Volker et al. (2012; Figure 5J), summarizes the geologic setting of southern Central Chile using recently published geophysical, seismological, sedimentological, and biogeochemical data and their outcome is an overview of the current knowledge about the geology. Stratigraphic studies provide a measure of sediment rates to match the volume distribution with the factors that are supposed to control the sediment input, and yields information about their effectiveness of latitudinal sediment transport within the trenches as identified in active continental margins (Völker et al., 2013). Stratigraphic studies are important to introduce the knowledge 
of hydrocarbons basins in offshore environments. Recent hydrocarbon exploration in offshore basins has led to the availability of numerous high-quality industry seismic and welllog datasets to the academic community (Gorini et al., 2014).

Several hydrocarbons studies were developed to rescue marine resources or something relating to an economic benefit (Benjamin et al., 2015; Isola et al., 2020). There has been an increase in the number of studies focused on hydrocarbon potential. That is the case of the Regência canyon study, which was induced mostly by a longer term ( $>400,000$ years) decrease in sediment supply, resulting in the investigation of the turbidites form oil reservoirs in the Lagoa Parda (LP) oil-field, located near the mouth of the Doce River (Bruhn and Walker, 1997; Figure 5O). Methods of reflection in continental margins by high-resolution seismic activity are developed in an attempt to find hydrocarbon reservoirs (López-Ramos, 2016). Marine seismic reflection cruises on continental margins have revealed deposits of gas hydrates, which are ice-like solids, constructed mainly from water that also contain a large concentration of gas (Rodrigo et al., 2009; Figure 5K).

\section{Marine Geohazards}

Marine geohazards studies are divided into four different categories: earthquake events, tsunami prediction, submarine landslide, and coastal erosion. Each of them is associated with a type of continental margin (active or passive). Active margin studies on earthquake events report a potential sediment mass movement caused by tectonic control as turbidites. To analyze the potential sediment mass movement, studies have used various limit equilibrium methods, with shear strength values obtained mainly from vane shear tests and less frequently from direct shear and triaxial compression tests (Busch and Keller, 1983). Studies aim to date the estimation of volume and sources of sediment to discuss their potential causes by comparing the frequency with the sea-level rise over the last $23 \mathrm{kyr}$, turbidites frequency over $\sim 5 \mathrm{kyr}$, and to measure earthquake events (Ratzov et al., 2010; Figure 5F). Aguilar et al. (2016; Figure 5D), have proposed by analysis of sediment cores that a large historical earthquake on the El Pilar fault had consequences on the sedimentation within the Gulf of Cariaco.

However, geohazards studies to understand the earthquake events have used other methodologies, for example based on a joint inversion of these events, obtained through the minimum $\mathrm{P}$ wave velocity model (Stow et al., 2012). The marine and terrestrial network, which work independently from each other, provided a broadly similar earthquake distribution at the Central Margin of Chile (Thierer et al., 2005; Figure 5I). Earthquake events are more common than we think and their signatures can be easily recorded by sediment core through structural patterns identified by seismicity networks throughout the world. Tréhu et al. (2020) have investigated the responses after the 2010 Maule earthquake using seismic high-resolution signatures of $\mathrm{S}$ and $\mathrm{P}$ waves, which have identified, as an example, 34 earthquakes located within at least six phase picks.

Earthquake events serve as a trigger to other processes in sequence, but this rule is not definite. Submarine landslides can also trigger a series of events depending on their magnitude
(Geist and Lynett, 2011; Clare et al., 2016; Camargo et al., 2019). According to Völker et al. (2009; Figure 5K), a large volumetric mass $\left(\sim 24 \mathrm{~km}^{3}\right)$ of displaced continental slope material that maintained much of its cohesion during the slump and run out process from a steep and high headscarp, suggested that a localized but dimensionally large and high tsunami could have been generated that was only counteracted by a large water depth of $4500 \mathrm{~m}$ of the source area. In active margins, submarine mass wasting is related to the tectonic control, where continuous uplift of the forearc across transgressive upper plate faults results in very steep slope gradients (Geersen et al., 2011).

Tsunami prediction studies provide their potential effects on the coast, when its magnitude can be increased by the seafloor topography as submarine canyons and coastal features behave as several resonators (Aranguiz and Shibayama, 2013; Aranguiz et al., 2019). As well as shelf promontories, which exhibit bathymetric features with regards to tsunamis, affecting their submerged cape morphology, a potential tsunami generated seawards of the promontory could cause a specific mode of propagation and coastal impact (Ioualalen et al., 2011). However, there is a challenge involving the prediction of tsunami risks, as its warning systems are increasing and becoming more accurate. Further, scenarios for identifying risk assessment by numerical simulation have been applied. Martínez et al. (2012) have analyzed the tsunami risk for an extreme event that allows to generate risk management criteria, to reconstruct the process of a given region by three different scenarios of risk assessment.

On the other hand, in passive margin, coastal erosion studies were developed to describe the dynamics of the shoreline position with submarine canyons as conductors of coarse sediment to the deep sea, and trails of depressions and sediment waves eroding submarine channels (Kokot, 2004; Heiniö and Davies, 2009). Bittencourt et al. (2001; Figure 5P), have monitored the morphodynamical variations of the beaches associated with an estuary contiguous through superposition of aerial photographs to show the presence of distinctive erosive and constructive cycles of low and high frequencies. Submarine landslide studies are also present in passive margin and focus on the sediment transport from the coast to the deep sea (Dalla Valle and Gamberi, 2011). According to Krastel et al. (2011), the continental margin of Uruguay and the de la Plata River extending into northern Argentina is an excellent site to study submarine sedimentation processes, their imprint on seabed morphology, and associated geohazards.

\section{Hydrodynamic Interactions}

Studies that focus on physical aspects are divided into three categories: upwelling, wind-driven, and paleoceanography. Almost all studies describe upwelling events relative to the more different contribution in advances of canyons as interacting with the systems of currents with seabed topographic features, that influence the mesoscale distribution and retention organisms (Valle-Levinson and Moraga-Opazo, 2006). The interaction between coastal topography, winds, and seasons have intensified upwelling as a complex system, involving transport, retention, and larval aggregation within mesoscale features as eddies and fronts (Vargas et al., 1997; Figure 5J). Amorim et al. (2012; 
Figure 5P), have established a first regional picture on the influence of large-scale circulation and transient processes, as well as local topographic features, on the seasonal eastern Brazilian shelf circulation.

Submarine canyons are regions of enhanced upwelling and cross-shelf exchange including nutrient flux onto the shelf (Hickey, 1997). Leth and Middleton (2004) have suggested a likely mechanism for the enhanced upwelling of the Gulf of Arauco region: wind-forced upwelling in conjunction with deep upwelling by a cyclonic eddy and shoreward advection by a headland eddy next to the Gulf. To upwelling mechanisms, the onshore cross-shore pressure gradient supports the alongshore geostrophic flow that breaks the geostrophic constraint as it interacts with the canyon topography, driving water into the canyon (Aguiar et al., 2018). The study looked at the adjustment of geostrophic currents, for example, and quasi geostrophic motion like coastal-trapped waves due to their abrupt variations of the bottom topography, modifying the coastal-trapped waves and their low-frequency energy, which can be dispersed into higher modes (Sobarzo et al., 2001).

Generally, physical aspects such as geostrophic currents, pressure gradient, and vorticity are the foundation of hydrodynamic interactions studies (Bravo et al., 2013), however, biological conditions of induction of productivity that arise from the upwelling circulation have been studied more frequently in association (Yannicelli et al., 2012). Also, measurement of high-productivity have increased together with hydrodynamic interactions, highlighting the potential of top-down control of the shelf production and export of nutrients (Vergara et al., 2017; Testa et al., 2018). Hence, an increase in biological communities has already impacted on nearby upwelling zones, mainly in submarine canyons. Landaeta et al. (2008) have described a series of processes acting at different spatial and temporal scales, as an interaction of the spawning behavior of marine fishes that inhabit the southern part of the Humboldt Current and the frequency of occurrence on mesoscale physical processes.

On the other hand, wind-driven studies are also carried out to describe the circulation models by topographic control nearby submarine canyons and upwelling processes. Sobarzo and Djurfeldt (2004) have characterized the physical development of the coastal upwelling process near Biobio and Itata canyons and its relation to local wind-forcing and the topographic control of the subinertial flow. Wind-driven processes promote a stronger variability in the water mass exchange between the canyon and the deep ocean near the surface, although the Japaratuba canyon seems to behave most of the time as a water export to the deep ocean, with reversed flow depending on the winds (DelGiovannino et al., 2000; Figure 5Q). Winds to act on transporting the sediment plume offshore, reducing the shelf stratification and increasing the chances of a full upwelling. In the Mar del Plata canyon, the occurrence of upwelling is interrupted by strong downwelling events, which tend to advect buoyant waters northward and back toward the shore, "capping" the upwelling center (Pimento et al., 2008; Figure 5L).

Wind-driven studies have been developed using different approaches such as upwelling studies. Studies to explain the formation of vortices in bay beaches, the establishing of currents and their interaction with the tide and local wind
(Leite et al., 2011), and to analyze the barotropic tidal currents and vortices (Aguirre et al., 2010), have illustrated the potential of top-down control of the shelf production and export of organic matter (Baird et al., 2007). Sobarzo et al. (2010) have presented the first analysis of diurnal-period wind variability and their current response. Intensity and seasonal cycles of winds create a unique coastal shelf environment with several special features. As a result, thermal stratification of the upper water column in spring and summer is governed by solar radiation, and temperature in the deeper water column is controlled by upwelling favorable wind stress (Sobarzo et al., 2007).

Lastly, the paleoceanography studies emerge to study the climate archive for paleoceanographic environmental reconstruction, to present different approaches about paleocurrent records for the Last Glacial Maximum (LGM), and offer paleoecological insights documenting past changes for anticipating future impacts on the environment (Warratz et al., 2017; Gu et al., 2019), all of them carried out in the Mar del Plata canyon (Figure 5L).

\section{Knowledge of Biological Communities}

Biological studies began in 2003 with five different natures of studies: vertical distribution, horizontal, taxonomy, ecology, and Marine Protected Areas (MPA). The vertical distribution is relative to nektonic and planktonic organisms that move in water columns, reaching the shallowest areas (Lauretta and Penchaszadeh, 2017; Bernal et al., 2019). Valle-Levinson et al. (2003; Figure 5J), have suggested two mechanisms that may cause the high primary productivity of the system of current and hydrographic variables in an equatorward facing bay adjacent to a coastal upwelling center. According to them, it is related to a persistent flow into the gulf through the deepest part nearby Biobio canyon and would be described with the diurnal variability in heat from ocean-atmosphere interactions and horizontal momentum from wind-driven stress, as mentioned previously. With the high frequency of semidiurnal tides, diurnal fluctuations superimposed onto others of lower frequency of wind-driven upwelling may contribute significantly to variations in the transport of individuals from bays in upwelling areas (Yannicelli et al., 2006).

Transport and retention are physical processes responsible for moving early pelagic life stages from the spawning site toward an appropriate nursery ground, influencing the regulation of recruitment and year-class strength (Landaeta et al., 2008). According to Castro (1993), knowledge of the location of nursery areas of fishes has been considered as a research requirement for the management of fisheries (Vazquez et al., 2016). On the other hand, the flow-topography interaction has also contributed to modify the vertical distribution and the intensity of its physical processes by upwelling zones which can impact the assemblage's variability. According to Rojas and Landaeta (2014), the combined effects of coastline and bathymetry on the upwelling circulation may generate a spatially structured coastal habitat where three types of fish larval assemblages can coexist.

To better understand the environment characteristics we decided to classify the horizontal distribution studies as associated with benthic organisms that have habitats and 
depend on the seafloor substrate to live. Benthic organisms are influenced by physical parameters such as temperature, salinity, and currents (de Araújo et al., 2018; Bremec and Schejter, 2019; Teso et al., 2019). However, chemical processes are mainly responsible for maintenance and variability of biological assemblages' distribution in submarine canyons where the nutrient exchanges are bigger than abyssal regions (Yamashita et al., 2018). Eichler et al. (2019; Figure 5T), have shown habitat preferences associated with different foraminiferal species in newly discovered environmental conditions and their potential to indicate paleo-upwelling and other environmental conditions. Bernardino et al. (2019; Figure 5N), have suggested that even with similar higher taxa composition, submarine canyons of E-SE Brazil host distinct assemblages individually and between canyon-slope habitats.

Ecology studies have compared benthic and fish communities to evaluate the relationship between their assemblages to study their eating habits and reproductive tactics (Schejter et al., 2014; Flores et al., 2019). Penchaszadeh et al. (2016) have described the egg mass of a moon snail from deep waters, and the findings of all intracapsular stages of development in the same expedition, including early stages and hatchlings as enormous crawling juveniles, may suggest a long reproductive season. Penchaszadeh et al. (2017) have contributed to the understanding of the reproductive modalities of the family Volutidae in the Mar del Plata canyon. According to them, all the species studied until now experience direct development and hatch as crawling juveniles. Physical and abiotic factors associated with seabed features have structured shallow water communities even within small spatial scales due to differences in local conditions, such as topography and currents, through nutrient-rich currents reaching them through the canyons and aiding primary productivity, or by a combination among these factors (Rovira et al., 2019).

Generally, taxonomy studies were carried out to describe new species identified following the morphological characteristics (Hasegawa et al., 2019), extending the known distribution range and a phylogenetic review of the genus (Pereira et al., 2019; Siegwald et al., 2020), but also to investigate the reproductive habits (Sánchez et al., 2018). Here, almost all taxonomy studies have approached the first report of a typical species related to submarine canyons environment as an effort to understand the biodiversity, spatial distribution, and habits of the biological communities and their relationship with these environments (Lauretta and Penchaszadeh, 2017; Martinez et al., 2019).

On the other hand, the MPA studies were carried out to understand the oceanographic characteristics that provide suitable foraging, reproductive, and spawn conditions and encourage conservation due to vulnerability and increasing economic interests at fishing areas. Schejter et al. (2016) have reported the most recent and complete checklist of benthic mega and macrofauna that summarized 240 taxa collected at three sites in the Namuncurá MPA. According to them, it will help detect indicator taxa vulnerable to trawling, recognize distribution patterns of the benthic organisms, and support management strategies. The MPA creation provides the identification of oceanographic processes that lead to prey availability which is fundamental for understanding the ecology of marine predators and developing conservation strategies for critical feeding ground habitats (Buchan and Quiñones, 2016). According to Almada and Bernardino (2017), any scenario of deep seabed mining within its EEZ, conservation actions need to anticipate bidding auctions and exploration off those areas in a similar way suggested for the offshore oil and gas industry, since those areas lack proper biological assessment and likely host unique and vulnerable assemblages.

\section{Pollution}

Marine pollution by submarine canyons is becoming an issue that can affect the environment in many different aspects. A single pollution study carried out in the Fernando de Noronha Archipelago was identified concerning submarine canyons (Ivar do Sul et al., 2013), which suggests the existence of an outward gradient of mean plastic-particle densities using biological assemblages.

Here, the marine litter study summarized an overview about how the pollution through submarine canyons can transform the whole environment, changing the sediment accumulation rate even in small proportions, modifying the flow as physical barriers and generating impacts on biological communities (Pierdomenico et al., 2019; Harris, 2020; Uddin et al., 2021). The South Atlantic region is expected to present an upward trend in land-based pollution sources as a result of increasing urbanization and industrialization in the coastal zone and the lack of comprehensive regulation, appropriated enforcement, and abatement (Hatje et al., 2021). Some islands are uninhabited, while others are occupied by a few to thousands of people. In the Caribbean Sea, the permanent and/or temporary occupation associated with high costs for waste disposal result in potential land-based sources of plastics depositing in hundreds of insular environments and surrounding waters (Monteiro et al., 2018, 2020).

Technological advances have influenced all types of studies which can be observed in the methods used, as well as the different natures of each of them (Supplementary Data Sheet 1).

\section{CHANGE OF KNOWLEDGE AND THE EVOLUTION OF CANYONS STUDIES}

Four groups of studies are observed in timeline: geodynamics (morphotectonics, depositional systems, and marine geohazards), physical (hydrodynamic interactions), biological (knowledge of biological communities) and social (pollution) studies. As a result, a sequence of arguments was followed for identifying some important aspects from submarine canyons studies in SA to analyze each of them and their link to the Ocean Decade.

Geodynamic studies are based on morphotectonic and depositional systems, since in the mid-1970s new methodologies triggered seabed mapping driven by technological advancements post World War II (Johnstone and McLeish, 2020). Seabed mapping is becoming faster due to the investigation of oil reservoirs, and also the emergence of studies carried out in offshore areas (Solheim et al., 2007). The high NUPPY is also 
related to the financial support of the main oil exploration companies which is observed nowadays (Rolin et al., 2013). Partnership between academy and industry is a trend that helps to map the EEZs regions considered of high potential for exploiting resources (Kerry et al., 2008). Depending on the location and investment sources, each EEZ may be partially or integrally linked to these resources (Voyer et al., 2018). Morphotectonic studies based on seabed mapping are observed practically along the whole timeline, even if they have emphasized only on technological development.

The climate change associated with sea level rise has increased the NUPPY realated to transport areas and sediment accumulation concentrated at mouths of rivers (Lavagnino et al., 2020). Studies on continental margins appear, where the methodologies are modified according to the purpose of each of them (Idárraga-García et al., 2019). As a result, sediment dynamics studies have investigated below the seabed to identify how oil reservoirs have changed to determine eustatic cycles (Gomes et al., 2016). Geomorphological changes promoted by the sea level rising have become the focus for increasing investments in technologies that anticipate the occurrence of extreme events in coastal zones (Ratzov et al., 2012). Studies included exploring the smallest to the largest sources of impact on coastal erosion (Kokot, 2004), classifying earthquakes with epicenters at sea (Ioualalen et al., 2011), and prediction of submarine landslides and tsunami risks (Krastel et al., 2011; Aranguiz and Shibayama, 2013).

Marine geohazards emerge to represent coastal erosion, earthquakes, submarine landslides, and tsunamis (Camargo et al., 2019). Most geohazard studies are associated with the active margin on the subduction zone (Nunn and Pastorizo, 2007), although they are also present on the passive margin (Krastel et al., 2011; Figure 5). In active margin, studies have investigated features of the seabed as pockmarks as an indication of possible areas of gas hydrate leaks and indicative of energy sources (de Mahiques et al., 2017), for mapping potential areas for the occurrence of extreme events as submarine landslides areas (Albertão et al., 2015). They have also aimed to introduce new techniques to predict extreme events and mitigate impacts (Michaud et al., 2015; Aranguiz et al., 2019).

Nevertheless, environmental social movements emerged to discuss the type of method used in marine surveys, leading to its reassessment and concern for the affected organisms (Lee et al., 2011). Studies based on the relationship of marine communities and their behavior appear in submarine canyon areas as bedforms (Lastras et al., 2011), type of substrate (Hagen et al., 1994), degree of inclination (Idárraga-García and León, 2019), depth changes (Bernal et al., 2019), and marine relief (Rojas and Landaeta, 2014). Currently, the race for oil exploration gives space to the advancement to so-called benthic geohabitats, being used as a trigger for the investment of public and private initiatives to develop new projects focusing on the knowledge of marine biological assemblages and their association with different oceanographic processes (Hernández-Molina et al., 2011; Ternes et al., 2020).

Physical studies are being carried out in active margins related with upwelling effect and its local biota association, mainly on the coast of Peru and Chile (Sobarzo et al., 2016). Although, the dimension of physical processes is not limited to upwelling zones and their influence on fishing areas (Montero et al., 2007; Yannicelli et al., 2012), but also by processes such as wind driven (Del-Giovannino et al., 2000; Sobarzo et al., 2010) and paleoceanography (Voigt et al., 2013; Gu et al., 2019). Instead, we have a complexity of elements inserted to better understand the oceanographic relationships of each margin.

The environmental characteristics are determined by their interactions with sediment input, rainfall regime, intensity and direction of winds and currents, water masses, and biological assemblages, affecting a high complexity region such as the Amazon River mouth (Figure 5A; Jegou et al., 2008; Lavagnino et al., 2020). The sediment distribution, as well as the flow dynamic in submarine canyons, are examples of how the flowtopography interaction is fundamental for the maintenance of these processes (Lorenzoni et al., 2012). Methodological advances, such as internal waves analysis (Aguirre et al., 2010), interaction of vorticity (Leth and Middleton, 2004), or even water masses intrusion at shelf-break (Bravo et al., 2013) have been a great influence in studies' evolution over the knowledge of physical processes that occur near coastal zones. The increase of NUPPY and development of hydrodynamic models suggest the flow-topography interactions were carried out to better understand the role of submarine canyons in the edge effects, and transport of water masses from deeper to shallower areas (Amorim et al., 2012; Aguiar et al., 2018).

The water column proprieties have changed the local ecosystems due to entry of more saline and cooler and nutrientrich waters from deeper regions. Variation in the trophic chain, depending on the intensity of their changes, transform from an initially oligotrophic to mesotrophic or even eutrophic environment (Medina et al., 2014). Submarine canyons areas have become the target of studies in the last decades, due to their fishing dynamic being of great importance to the economy with studies exploring fishing areas (Katsanevakis et al., 2011; Camargo et al., 2015), and social aspect impacting publications for the creation of MPA, responsible for maintenance and conservation of marine life (Almada and Bernardino, 2017).

Biological studies approach two perspectivies, (1) biological of benthic organisms and their reproductive tactics and (2) processes of the derivation of fish larvae and other organisms that belong to water column (Yannicelli et al., 2006; Landaeta et al., 2008). Studies have demarcated the distribution areas, being horizontal for benthic communities (Molina et al., 2004) or vertical for nektonic organisms (Rovira et al., 2019). Studies which emphasize the creation of MPA's have become more frequent as a result of surveys of biodiversity and delimitation of organisms' distribution (Schejter et al., 2016; Yamashita et al., 2018). As a result, an increase of knowledge of biological communities studies have discovered new species and biodiversity hotspots nearby submarine canyons, such as the research developed on the Argentine coastline (Lauretta and Martinez, 2019; Teso et al., 2019).

To the social group, Brazil has an unprecedented publication in the timeline with a focus on pollution that is related to microplastics in the Fernando de Noronha archipelago which 
have mentioned submarine canyons and their association with marine litter (Ivar do Sul et al., 2013). Although this study does not show results related to canyons as vectors of dispersion of pollutants in the oceans, it demonstrates a trend established nowadays, due to the spread of the impacts caused by the uncontrolled use of plastic (Cau et al., 2017; Monteiro et al., 2018).

\section{ADVANCES, GAPS, AND FORECASTING FROM SUBMARINE CANYONS AND THEIR LINK TO THE OCEAN DECADE}

Submarine canyons studies are being developed due to the increase of interest for new perspectives about the land-ocean system (Tubau et al., 2015; Fernandez-Arcaya et al., 2017). Investments and politics that support creating more beneficial conditions for practical applications of new knowledge and technology are more present in the world framework in association with organized actions to achieve transformational ocean science (Ryabinin et al., 2019; IOC-UNESCO, 2021). To provide solutions that will deliver optimal benefits to ocean science which is co-designed by a diverse range of stakeholders needs to be nothing short of a revolution in the way we generate and use ocean science (IOC-UNESCO, 2021), and promote sustainable development, to manage spatial uses and conflicts in marine areas (Steenbeek et al., 2020).

Systematically, initiatives around submarine canyons studies are following scientific discussions focused on the ocean's future, i.e., to develop an efficient politic of actions for building the ocean that we want and its perspectives for future generations. The Ocean Decade emerges as a revolution with the mission to catalyze transformative ocean science solutions for sustainable development, connecting people and our ocean. Submarine canyons studies have been presented as a Decade contribution that supports the Decade through provision of a necessary resource or implementation of a Decade Actions or even the coordination function of the Decade. The influence of the Ocean Decade as change in the trend of study's types with submarine canyons in SA can contribute to the advancement of knowledge and development of new approaches into the Decade overview.

A series of scientific marine content should be integrated to accomplish the Decade development. According to the IOCUNESCO (2021), among the Decade Objectives, objective 1 summarizes the urgent need for knowledge for regular integrated assessments of the state of the ocean and of ocean science capacity, promotion of new technology and increased access to technology, enhancement and expansion of observations infrastructure, and development of mechanisms to optimize citizen science initiatives. Objective 2 involves the mapping and understanding of ocean components, understanding of thresholds and tipping points for the ocean system, increased use of historical ocean knowledge, improved ocean models and prediction services, and increased efforts in education, training, and transfer of marine technology. Objective 3 involves understanding of the role of ocean science in the development of interoperable and open-access data platforms and services, facilitation of co-designed and co-delivered ocean solutions including planning, management, and other tools and services, and the promotion of formal and informal education.

The evolution of SA canyons studies is included in the third objective. According to the timeline, we can observe two well-marked divisions, one from 1970 to 2000 and the other from 2001 onward. At first, studies with submarine canyons were not well structured and present several gaps between periods of publication. Although we have known the importance of these environments, the focus of studies with submarine canyons in the 70 s, 80 s, and 90 s were not heavily publicized among the academic community (Figure 2), except for those that intended to map the seafloor as a framework for knowledge advancement. The Nippon Foundation-GEBCO Seabed 2030 Project in partnership with Scripps Institution of Oceanography at the University of California San Diego is an example of it. They have strengthened their collaboration with a newly established Memorandum of Understanding (MOU) which has as its main purpose to pursue the attainment of worldwide bathymetric data, and to increase human understanding of the oceans. Also, GEBCO is a joint project of the International Hydrographic Organization (IHO) and the Intergovernmental Oceanographic Commission (IOC). The Nippon Foundation-GEBCO Seabed 2030 Project. (2021). https://seabed2030.org/news/nippon-foundation-gebco-seabed2030-project-announces-new-collaboration-scripps-institution [Accessed August 24, 2021].

In canyon areas, the technology and time of survey are still limit the advance of studies in such vast, hostile, and difficult to access environments (He et al., 2014). The constancy of events close to the coastal zone makes the region of continental margins one of the most dynamic places, whether due to the presence of natural or extreme events (Gao and Collins, 2014). From the 2000s, we can see a slight increase in the NUPPY concerning submarine canyons, maintaining diversity, and exploration of content to the present day (Figure 2). It is important to search for better comprehensive knowledge of the continental margins, with advancement of the Ocean Decade insights in the last years and the association of new technologies for detailed mapping of the oceans provided an increment in the NUPPY relate to scientific ocean research, including submarine canyons studies. The difference in study number is associated with the infrastructure availability and research incentives given for each country (Fernandez-Arcaya et al., 2017).

However, gaps are not only temporal but also spatial, which we can observe in the studies approach which is inserted in a period of the timeline. The information crossing shows that submarine canyons studies in SA follow a complex development trend, with a predominantly QL approach at the beginning, QLQT at the end, and isolated points of ID studies throughout the timeline (Figure 3). Several factors could be associated, such as the lack of investments and specialized training seen in some regions, due to specific interest and method of publication of each country, or due to technological limitations added to geographical barriers in areas of difficult access (Kelley et al., 2014). Although it is not appropriate to attribute its behavior and generalize only to these arguments, we must highlight technology as one of the main 
reasons and add an important aspect within the issue of the gaps: Ocean Science Diplomacy.

According to Polejack and Coelho (2021), the lack of investments is hampering studies in Latin America and the Caribbean from accessing and using marine technologies to develop the science needed to inform decisions and international negotiation processes on an equitable basis. They also emphasize that researchers from developed countries often access funding and infrastructure to conduct research in Latin America and the Caribbean waters. However, researchers usually apply only a small portion of the funding in the foreign field, leaving local contributors with limited access to research equipment. Most marine research in the southern hemisphere has a limited research budget with highly fluctuating exchange rates, that is spent in keeping up with international standards which determine data accuracy, thus allowing replicability and comparison (Polejack and Coelho, 2021). As a gap, the lack of investments can be observed in almost all submarine canyons studies in SA, influencing the smallest NUPPY of Group 2 seen in Group 1 (Figure 3) and diversity of studies per country (Figure 5).

Nevertheless, we must also consider the Blue Economy as an important approach within the gaps. However, the Blue Economy's approach is complex and needs to comply with several aspects to be applied coherently. The activity scale includes aspects such as the type of activity, the service the activity is providing, established and emerging industries, growth drivers for sustainable industrialization, and technological development of important countries to marine science. For Golden et al. (2017), the increased industrialization challenges the traditional paradigm of jurisdictional control of waters and seabed features within national exclusive economic zones (EEZs). According to the authors, this strain is currently becoming apparent in three different spheres: (1) nations' capacities to govern the waters within their EEZs, (2) the international community's capacity to regulate international waters, and (3) the ability of industrial and financial institutions to reach consensus on forms of selfgovernance.

Smith-Godfrey (2016) and Golden et al. (2017) have identified activities relating to the oceans which both have similar proposals for the activity's development like the Ocean Decade Challenges. Although, it is necessary to realize that they will not be the same for all countries since the management of marine spatial planning processes is not equal. As a result, a contrast in the evolution of submarine canyons studies have been observed in SA with concentrations on different types and natures of studies, identifying a specific country as a major focus of publication with each subject (morphotectonics, depositional systems, marine geohazards, hydrodynamic interaction, knowledge of biological communities, or pollution) (Figure 4).

According to Golden et al. (2017), to change this scenario would be to reimagine the oceans as a shared space and a resource capable of providing social, environmental, and economic goods, but only if transparency, coordination, and the commitment to balance competing objectives are at the forefront of public policy and governance, finance, and management of global supply chains. As well as technological development and the entire management process for planning the use of marine space, all of this is included as an economic factor that can be represented in the NUPPY variation for submarine canyons surveys for the SA. Economic activities within the Blue Economy are fundamental for the investment of new perspectives for canyons studies throughout the world. Although, Latin America and the Caribbean struggle to conduct marine scientific research and seize the opportunities of Blue Economy due to their limited access to state-of-the-art technology (Polejack and Coelho, 2021). The Blue Economy has contributed to the development of submarine canyons studies as well as the formation of the Ocean Decade Challenges based on seven most urgent social outcomes.

The Ocean Decade (2021-2030) appears as an aspect oscillating between gaps and forecasts because it is structured as the main vector that will lead the evolution of the relationship between humans and the sea, although it is still in the beginning development process (Ryabinin et al., 2019; Heymans et al., 2020; Polejack, 2021; Polejack and Coelho, 2021). As a gap, the Decade Challenges as seven outcomes are still obstacles to be overcome, and probably the change will not occur only within the given period. We must highlight how those studies with submarine canyons in SA are framed in this scenario, even when they are ambiguous, behaving sometimes as a gap or as forecasts. Nevertheless, they play a strong role within environmental study, contributing to the understanding of the types of processes and actors involved in the horizontal transition zones, marked by the land-ocean limit, and vertically defined by the balance of oceanographic components present in the water column.

As a forecast, ignoring the fact that pro-ocean actions have been gaining strength due to the initiatives promoted by the Ocean Decade is a contradictory attitude, especially due to the impact generated in various geopolitical, economic, and social spheres (Steenbeek et al., 2020). Generally, when we approach forecasts concerning marine science in any aspect, we find an immediate association with the Ocean Decade Challenges and their social outcomes. It is practically impossible to talk about the future of the oceans and not relate to any objectives mentioned for the decade.

\section{The Decade Challenges as an Overview for the Future of Submarine Canyons Studies}

We saw here that each study approach related to submarine canyons had a relationship to one outcome mentioned in the Ocean Decade Challenges. This relationship was presented in the following chronological order according to the timeline of submarine canyons studies in SA relative to the decade outcomes, as discussed previously. The Ocean Decade Challenges summarizes the needs based on: (1) A clean ocean, through identifying and removing sources of pollution; (2) A healthy and resilient ocean, with mapped and protected marine ecosystems; (3) A predicted ocean, enabling society to understand current and future ocean conditions; (4) A safe ocean, protecting people from ocean hazards; (5) A sustainably harvested and productive ocean, providing food and resources for the blue economy; (6) A transparent and accessible ocean, giving citizens equitable 
access to data, information, and technologies; and (7) An inspiring and engaging ocean, which here, serves as a cycle of marine events to outcomes where society understands and values the ocean in relation to human wellbeing and sustainable development (Figure 6).

(6) Morphotectonics and a transparent and accessible ocean, giving citizens equitable access to data, information, and technologies. In morphotectonic studies, the evolution of technology has provided improvements in the collection method and, consequently, the increased interest in studies in areas of submarine canyons. Although the efforts of morphotectonics studies to map and study the seafloor is in order to produce a "transparent and accessible" ocean, the enormous need for more ocean information in the scientific, governmental, private, and public sectors demands a change in ocean education at all levels (Ryabinin et al., 2019). Morphotectonic studies have presented a consistent proposal over marine research, evaluating new technologies, methods, and approaches for understanding submarine topography. Also, the challenges into the MSP have been designed to help decision makers, stakeholders, and students understand and manage the maritime Blue Economy and marine environment.

As well as objective (1) posed by the Ocean Decade, which includes sub-objectives related to the provision of knowledge for regular integrated assessments of the state of the ocean and of ocean science capacity, the promotion of new technology and increased access to technology, enhancement and expansion of observations infrastructure, and development of mechanisms to optimize citizen science initiatives and the recognition and inclusion of local and indigenous knowledge is also crucial (IOCUNESCO, 2021). Thus, we can associate morphotectonic studies with the Decade Challenge (6) "a transparent and accessible ocean," that forecasts how advances of new technologies and the digital revolution are transforming the ocean sciences to deliver data and information to all stakeholders (Ryabinin et al., 2019).

(5) Depositional systems and a sustainably harvested and productive ocean, providing food and resources for the Blue Economy. This concerns the exploitation of sea resources, spatially led by oil prospecting in offshore areas and later by fishing surveys in areas nearby canyons, considered biodiversity hotspots. Observing the development of depositional systems studies, we can include them in two goals that seek to strengthen global partnerships to achieve the targets of the 2030 Agenda for the Ocean Decade: (1) Knowledge and solutions for a sustainable ocean economy and (2) Knowledge and solutions for low-impact ocean energy. Hence the depositional systems should be included on Decade Challenge (5) "a sustainably harvested and productive ocean" which should create a better understanding of the interactions and interdependencies of the ocean ecosystem and environmental conditions and processes and the use of resources and the economy. According to Ryabinin et al. (2019), this is a major task in context of the development of the ocean economy that will document the potential impacts from environmental changes on the established and emerging maritime industries and their ability to generate growth, especially for least developed countries and Small Island Developing States (SIDS).

(4) Marine geohazards and a safe ocean, protecting people from ocean hazards. The objective is based on marine geohazard studies, giving visibility to the most common events, such as coastal erosion, to the most impactful, such as earthquakes, submarine landslides, and tsunamis, present on active continental margins, or coastal erosion in passive margins. Marine geohazards are one of the challenges established for the Ocean Decade to attempt to understand how they can impact the coastal zone in social, economic, and environmental ways. Therefore, it is important to enhance multi-hazard early warning services for all geophysical, ecological, biological, weather, climate, and anthropogenic-related ocean and coastal hazards, and mainstream community preparedness and resilience (IOCUNESCO, 2021). According to Ryabinin et al. (2019), the decade will promote research aimed at minimizing impacts of various changes and risk reduction through adaptation and mitigation, contributing to enhanced preparedness and awareness of society with regard to ocean risks. Thus, for the Ocean Decade, submarine geohazards are concerning the Decade Challenge (4) "a safe ocean," whereby human communities are much better protected from ocean hazards and where the safety of operations at sea and on the coast is ensured (Ryabinin et al., 2019).

(3) Hydrodynamic interactions and a predicted ocean, enabling society to understand current and future ocean conditions. This concerns hydrodynamic interactions studies, highlighting the upwelling effect, the dynamics of currents, water mass flows, and their interactions with other oceanographic processes in submarine canyons. Hydrodynamic interactions studies have discussed the gaps between ocean-atmosphere interactions and the effects of climate changes to ensure that physical aspects and their variability of proprieties, especially within the water column, are known more deeply. For the decade challenge, it is important to enhance understanding of the oceanclimate nexus and generate knowledge and solutions to mitigate, adapt, and build resilience to the effects of climate change across all geographies and at all scales to improve services including predictions for the ocean, climate, and weather (IOC-UNESCO, 2021).

Studies based on modeling and prediction of the seasonality of upwelling events and their impacts on the whole environment with transport of nutrients from deeper to shallowest areas are fundamental to the management of fishing areas. According to Ryabinin et al. (2019), knowledge of present and future conditions is a pre-requisite to the development of sustainable ocean economic policies and ecosystem-based management, and through systematic ocean observations under the Ocean Decade, it would be possible to map all ocean basins to initialize coupled models and facilitate improved ocean understanding. 


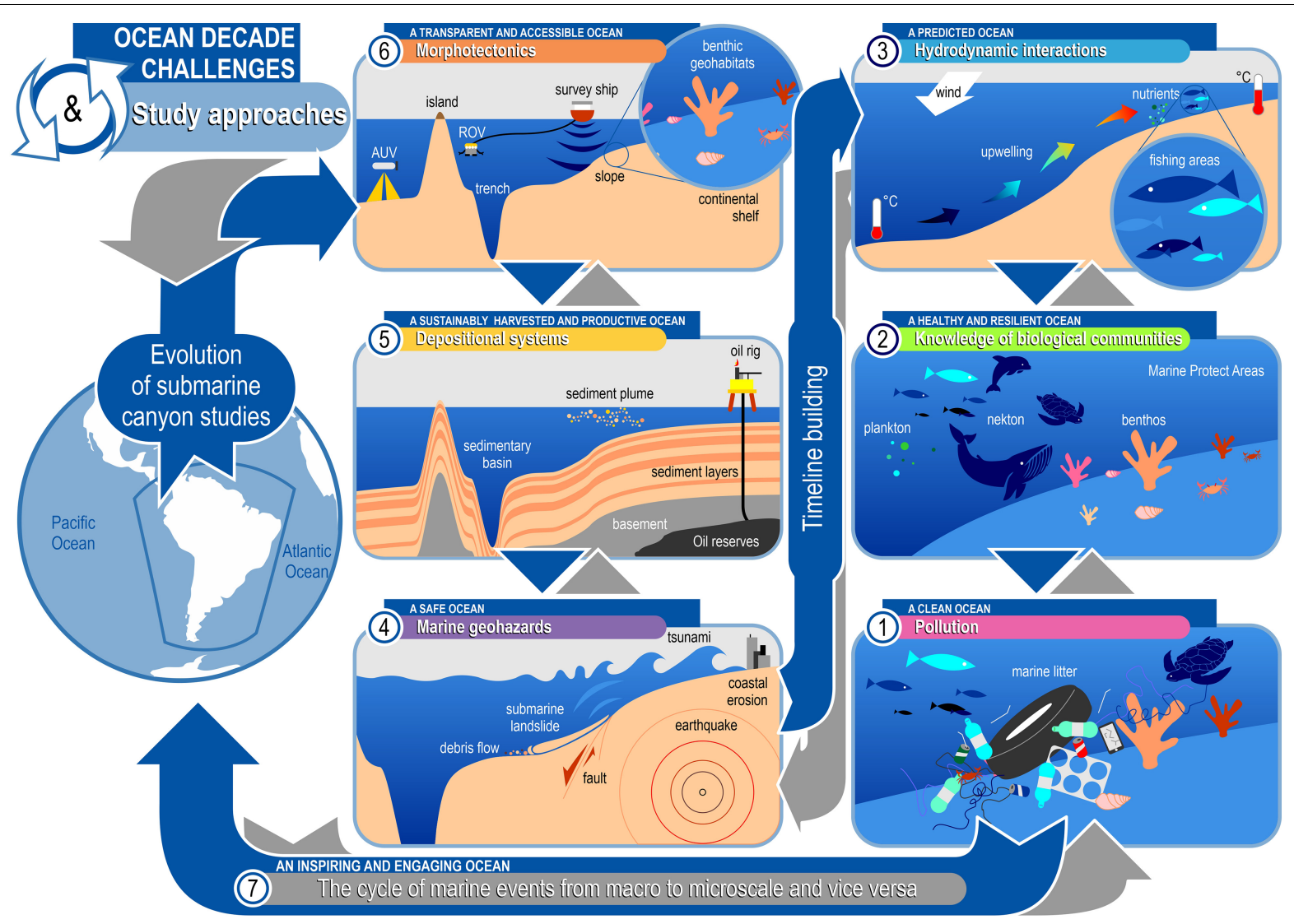

FIGURE 6 | Cycle of marine events following chronological order according to the timeline of submarine canyons studies in South America relative to the Ocean Decade outcomes.

Hence, hydrodynamic interactions studies can be inserted on the Decade Challenge (3) "a predicted ocean" which has the capacity to understand current and predict future ocean conditions and their impact on human well-being and livelihoods (Ryabinin et al., 2019).

(2) Knowledge of biological communities and a healthy and resilient ocean, with mapped and protected marine ecosystems. Biological communities' studies in submarine canyons compose the framework for comparing social outcomes, focused on the creation of Marine Protection Areas because of surveys of biodiversity and the delimitation areas of the distribution of organisms. Biological studies are a response to geodynamics (morphotectonics, depositional systems, and geohazards) and physical studies. Biological studies have a vertical distribution of planktonic and nektonic organisms in the water column influenced by physical proprieties, and horizontal distribution of benthic organisms on the seabed substrate based on sediment characteristics. Each group has an important ecological role for understanding the complexity of the marine biological assemblages and their interactions to provide a biodiverse environment. It leads to conservation of the MPA's nearby canyon areas, i.e., biodiversity hotspots.

Knowledge of biological communities' studies are important for the knowledge of and solutions for management of ecosystems faced with multiple stressors (IOC-UNESCO, 2021), evaluating the economic and societal value of the ocean and its ecosystems to stimulate marine spatial planning, MPA, coastal zone management, and other ecosystem-based management approaches (Ryabinin et al., 2019). Thus, the biological communities' studies can be inserted on Decade Challenge (2) "a healthy and resilient ocean" in which (Ryabinin et al., 2019) marine ecosystems are protected, elucidating impacts of cumulative stressors on the ocean, its seas, ecosystems, and resources, hence providing required information to enable actions, which can reverse the ocean ecosystem degradation.

(1) Pollution and a clean ocean, through identifying and removing sources of pollution. Finally, we relate the Ocean Decade to the first pollution study in association with submarine canyons and the confirmation of a strong trend line regarding the advances in pollution research in the oceans. However, the reversal of the degradation cycle will evolve not only through research and development of innovative solutions in individual institutions but also 
through collaborations between national and international groups of stakeholders, including scientists, traditional communities, indigenous peoples, and the private sector who could contribute with their experience, time, and other resources (Hatje et al., 2021).

Thus, the Decade Challenge (1) "a clean ocean" should be related to pollution studies which assume integrated research will assess the human and environmental shorter-term and longterm risks from ongoing and future types of ocean pollution and generate new ideas on how to reduce ocean pressures by recycling, improved waste management, and strengthening the governance regimes that encourage more sustainable production and consumption (Ryabinin et al., 2019). Ensuring that the most vulnerable environments are properly protected from pollution and its consequences requires the early establishment of agreements, protections, and policies that will minimize social inequality and secure a clean ocean (Hatje et al., 2021).

All of these are based on the unique opportunity to change the way we support sustainable development and galvanize ocean sciences for future generations (Ryabinin et al., 2019; IOC-UNESCO, 2021; Hatje et al., 2021). Therefore, we can understand a little better how submarine canyons studies are being developed over the years in SA. Also, we observe the period with the highest NUPPY, the person responsible for the publication, the main approach, the importance of the location of the studies, and the type of studies identified in each study. Parallelly, we have the timeline to understand the evolution of studies and their role in the overview for the future, demonstrating how it is inevitable to dissociate the relationships among geological, physical, biological, and social (economical) conditions in spatiotemporal analysis and type of studies.

\section{CONCLUSION}

To advance submarine canyons studies, we have geodynamic studies at the base of evolutionary overview. Morphotectonic studies explore seafloor investigation and development of new technologies for data collection in areas of difficult access. The interest in understanding sedimentological processes is increasing, with the first studies on sea level rise, eustatic cycles, and seismic stratigraphy on the continental margins. Marine geohazards are presented as events impacting the coastal zone. Differences between the types of geohazards and their link to active and passive margins are observed. The physical studies of hydrodynamic interactions arise to further restrict this scenario. The upwelling zones have influenced the fishing areas, even the interactivity between the processes is important for building the environmental conditions leading to the nutrients' distribution and biodiversity close to the submarine canyons. The behavior of biological communities is a response to these events, which has a vertical distribution of planktonic and nektonic organisms in the water column and horizontal distribution of benthic organisms on the substrate. Each group has an important ecological role in understanding the complexity of the marine organisms and their interactions as biodiversity environments to establish the conservation of the MPA nearby canyon areas as biodiversity hotspots. In addition, we have pollution as a source of impact on all aspects mentioned above. Marine litter deposits on the seabed, in addition to polluting the environment causing impacts on biological communities, can also modify the sediment accumulation rate even in small proportions and alter the flow as they are considered physical barriers, especially close to submarine canyons.

In summary, we observed that the spatiotemporal distribution of submarine canyons studies is different in two types of margins (active and passive), as it interferes with the way that studies will be carried out. It is also evident that the main reasons for it are associated with geological, physical, biological, or social processes. Moreover, economic investments generated by Blue Economy and the evolution of new technologies are two aspects that occur simultaneously and, therefore, are fundamental to understanding the overview of submarine canyons studies in SA. As future steps, the development of new technologies to map the seafloor appear as a link of interaction between two geological aspects to an environmental approach with the emergence of a new trend in marine science, the so-called benthic geohabitats, to promote sustainable development, knowledge, and marine environments disclosure.

As well as the three main objectives proposed by the Ocean Decade (IOC-UNESCO, 2021), the change of knowledge on submarine canyons studies in SA play an important role in: (1) Increasing the capacity of ocean science to deliver needed ocean data and information; (2) Generating comprehensive knowledge and understanding of the ocean including human interactions, and their interactions with the atmosphere and the land sea interface; and (3) Increasing the use of ocean knowledge and understanding, and developing the capacity to contribute to development human-ocean solutions. To progress in several thematic areas of ocean science, it is necessary that most societal outcomes are awarded action by society, governments, or by key stakeholders. It is essential that ambitions of the private sector, governments, and involved managers grow along with the progress in research. Also, active, intensive, and efficient communication of advances on ocean sciences should be a key enabling factor (Ryabinin et al., 2019). As a result, an overview about the spatiotemporal trends of submarine canyons studies in SA was developed to describe the timeline building and to know what its relationship is to the Ocean Decade outcomes.

\section{DATA AVAILABILITY STATEMENT}

The original contributions presented in the study are included in the article/Supplementary Material (Supplementary Data Sheet 1), further inquiries can be directed to the corresponding author.

\section{AUTHOR CONTRIBUTIONS}

All authors listed have made a substantial, direct, and intellectual contribution to the work, and approved it for publication. 


\section{FUNDING}

This work was a contribution to the Projects Ciências do Mar II (AUXPE 1979/2014-CAPES), INCT AmbTropic - Brazilian National Institute of Science and Technology for Tropical Marine Environments (565054/2010-4, 8936/2011, and 465634/2014-1, CNPq/FAPESB/CAPES).

\section{ACKNOWLEDGMENTS}

We dedicate this manuscript to everyone involved for their trust and support when needed during the completion of each stage. Special thanks to the psychology group at the Federal University

\section{REFERENCES}

Aguiar, A. L., Cirano, M., Marta-Almeida, M., Lessa, G. C., and Valle-Levinson, A. (2018). Upwelling processes along the south equatorial current bifurcation region and the salvador canyon (13 $\left.{ }^{\circ} \mathrm{S}\right)$, Brazil. Cont. Shelf Res. 171, 77-96. doi: 10.1016/j.csr.2018.10.001

Aguilar, I., Beck, C., Audemard, F., Develle, A. L., Boussafir, M., Campos, C., et al. (2016). Last millennium sedimentation in the Gulf of Cariaco (NE Venezuela): evidence for morphological changes of gulf entrance and possible relations with large earthquakes. Comptes Rendus Geosci. 348, 70-79. doi: 10.1016/j.crte.2015. 10.001

Aguirre, C., Pizarro, O., and Sobarzo, M. (2010). Observations of semidiurnal internal tidal currents off central Chile $\left(36.6^{\circ} \mathrm{S}\right)$. Cont. Shelf Res. 30, 1562-1574. doi: 10.1016/j.csr.2010.06.003

Albertão, G. A., Eschard, R., Mulder, T., Teles, V., Chauveau, B., and Joseph, P. (2015). Modeling the deposition of turbidite systems with Cellular Automata numerical simulations: a case study in the Brazilian offshore. Mar. Pet. Geol. 59, 166-186. doi: 10.1016/j.marpetgeo.2014.07.010

Alfaro, E., and Holz, M. (2014). Seismic geomorphological analysis of deepwater gravity-driven deposits on a slope system of the southern Colombian Caribbean margin. Mar. Pet. Geol. 57, 294-311. doi: 10.1016/j.marpetgeo.2014.06.002

Almada, G. V. M. B., and Bernardino, A. F. (2017). Conservation of deep-sea ecosystems within offshore oil fields on the Brazilian margin, SW Atlantic. Biol. Conserv. 206, 92-101. doi: 10.1016/j.biocon.2016.12.026

Almeida, N. M., Vital, H., and Gomes, M. P. (2015). Morphology of submarine canyons along the continental margin of the Potiguar Basin, NE Brazil. Mar. Pet. Geol. 68, 307-324. doi: 10.1016/j.marpetgeo.2015.08.035

Amorim, F., Cirano, M., Soares, I. D., Campos, E. J. D., and Middleton, J. F. (2012). The influence of large-scale circulation, transient and local processes on the seasonal circulation of the Eastern Brazilian Shelf, $13^{\circ}$ S. Cont. Shelf Res. 32, 47-61. doi: 10.1016/j.csr.2011.10.011

Aranguiz, R., and Shibayama, T. (2013). Effect of submarine canyons on tsunami propagation: a case study of the biobio canyon, Chile. Coast. Eng. J. 55:22. doi: 10.1142/S0578563413500162

Aranguiz, R., Catalán, P. A., Cecioni, C., Bellotti, G., Henriquez, P., and González, J. (2019). Tsunami resonance and spatial pattern of natural oscillation modes with multiple resonators. J. Geophys. Res. Ocean. 124, 7797-7816. doi: 10.1029/ 2019JC015206

Armijo, R., Lacassin, R., Coudurier-Curveur, A., and Carrizo, D. (2015). Coupled tectonic evolution of andean orogeny and global climate. Earth Sci. Rev. 143, 1-35. doi: 10.1016/j.earscirev.2015.01.005

Baird, M. E., Leth, O., and Middleton, J. F. (2007). Biological response to circulation driven by mean summertime winds off central chile: a numerical model study. J. Geophys. Res. Ocean. 112, 1-15. doi: 10.1029/2006JC003655

Benjamin, U., Huuse, M., and Hodgetts, D. (2015). Canyon-confined pockmarks on the western Niger Delta slope. J. African Earth Sci. 107, 15-27. doi: 10.1016/ j.jafrearsci.2015.03.019

Bernal, M. C., Cairns, S. D., Penchaszadeh, P. E., and Lauretta, D. (2019). Errina argentina sp. nov., a new stylasterid (Hydrozoa: Stylasteridae) from Mar del of Pernambuco for their therapeutic support in the pandemic period. We would also like to thank the Geological Oceanography Laboratory for providing adequate facilities for the development of this study, even in a pandemic period. We thank Raqueline Monteiro for exchanging information about the Ocean Decade theme.

\section{SUPPLEMENTARY MATERIAL}

The Supplementary Material for this article can be found online at: https://www.frontiersin.org/articles/10.3389/fmars. 2021.764029/full\#supplementary-material

Plata submarine canyon (Southwest Atlantic). Mar. Biodivers. 49, 833-839. doi: 10.1007/s12526-018-0861-1

Bernardino, A. F., Gama, R. N., Mazzuco, A. C. A., Omena, E. P., and Lavrado, H. P. (2019). Submarine canyons support distinct macrofaunal assemblages on the deep SE Brazil margin. Deep. Res. Part I Oceanogr. Res. Pap. 149:103052. doi: 10.1016/j.dsr.2019.05.012

Bernhardt, A., Hebbeln, D., Regenberg, M., Lückge, A., and Strecker, M. R. (2016). Shelfal sediment transport by an undercurrent forces turbidity current activity during high sea level along the Chile continental margin. Geology 44, 295-298. doi: 10.1130/G37594.1

Bernhardt, A., Melnick, D., Hebbeln, D., Lückge, A., and Strecker, M. R. (2015). Turbidite paleoseismology along the active continental margin of chile - feasible or not? Quat. Sci. Rev. 120, 71-92. doi: 10.1016/j.quascirev.2015.04.001

Berton, F., and Vesely, F. F. (2016). Seismic expression of depositional elements associated with a strongly progradational shelf margin: northern Santos Basin, southeastern Brazil. Brazilian J. Geol. 46, 585-603. doi: 10.1590/23174889201620160031

Bittencourt, A. C. S. P., Lessa, G. C., Dominguez, J. M. L., Martin, L., Vilas Bôas, G. S., and Farias, F. F. (2001). High and low frequency erosive and constructive cycles in estuarine beaches: an example from Garcez Point. Bahia/Brazil. An. Acad. Bras. Cienc. 73, 598-610. doi: 10.1590/s0001-37652001000400013

Bravo, L., Ramos, M., Sobarzo, M., Pizarro, O., and Valle-Levinson, A. (2013). Barotropic and baroclinic semidiurnal tidal currents in two contrasting coastal upwelling zones of Chile. J. Geophys. Res. Ocean. 118, 1226-1238. doi: 10.1002/ jgrc. 20128

Bremec, C. S., and Schejter, L. (2019). Chaetopterus antarcticus (Polychaeta: Chaetopteridae) in argentinian shelf scallop beds: from infaunal to epifaunal life habits. Rev. Biol. Trop. 67, S39-S50. doi: 10.15517/rbt.v67iS5.38924

Bruhn, C. H. L., and Walker, R. G. (1995). High-resolution stratigraphy and sedimentary evolution of coarse- grained canyon-filling turbidites from the upper cretaceous transgressive megasequence, Campos Basin, offshore Brazil. J. Sediment. Res. B Stratigr. Glob. Stud. 65, 426-442. doi: 10.1306/d426827a2b26-11d7-8648000102c1865d

Bruhn, C. H. L., and Walker, R. G. (1997). Internal architecture and sedimentary evolution of coarse-grained, turbidite channel-levee complexes, early eocene regencia canyon, Espirito Santo Basin, Brazil. Sedimentology 44, 17-46.

Buchan, S. J., and Quiñones, R. A. (2016). First insights into the oceanographic characteristics of a blue whale feeding ground in northern Patagonia, Chile. Mar. Ecol. Prog. Ser. 554, 183-199. doi: 10.3354/meps 11762

Busch, W. H., and Keller, G. H. (1983). Analysis of sediment stability on the peru-chile continental slope. Mar. Geotechnol. 5, 181-211. doi: 10.1080/ 10641198309379842

Butler, L. W. (1970). Shallow Structure of the continental margin, Southern Brazil and Uruguay. Bull. Geol. Soc. Am. 81, 1079-1096.

Callow, R. H. T., Kneller, B., Dykstra, M., and McIlroy, D. (2014). Physical, biological, geochemical and sedimentological controls on the ichnology of submarine canyon and slope channel systems. Mar. Pet. Geol. 54, 144-166. doi: 10.1016/j.marpetgeo.2014.02.016 
Calvès, G., Auguy, C., de Lavaissière, L., Brusset, S., Calderon, Y., and Baby, P. (2017). Fore-arc seafloor unconformities and geology: insight from 3-D seismic geomorphology analysis, Peru. Geochemistry, Geophys. Geosystems 18, 3062-3077. doi: 10.1002/2017GC007036

Camargo, J. M. R., Araújo, T. C. M., Ferreira, B. P., and Maida, M. (2015). Topographic features related to recent sea level history in a sediment-starved tropical shelf: linking the past, present and future. Reg. Stud. Mar. Sci. 2, 203-211. doi: 10.1016/j.rsma.2015.10.009

Camargo, J. M. R., Silva, M. V. B., Júnior, A. V. F., and Araújo, T. C. M. (2019). Marine geohazards: a bibliometric-based review. Geosci. 9:100. doi: 10.3390/ geosciences 9020100

Castro, J. I. (1993). The shark nursery of Bulls Bay, South Carolina, with a review of the shark nurseries of the southeastern coast of the United States. Environ. Biol. Fishes 38, 37-48. doi: 10.1007/BF00842902

Cau, A., Alvito, A., Moccia, D., Canese, S., Pusceddu, A., Rita, C., et al. (2017). Submarine canyons along the upper Sardinian slope (Central Western Mediterranean) as repositories for derelict fishing gears. Mar. Pollut. Bull. 123, 357-364. doi: 10.1016/j.marpolbul.2017.09.010

Clare, M. A., Hughes Clarke, J. E., Talling, P. J., Cartigny, M. J. B., and Pratomo, D. G. (2016). Preconditioning and triggering of offshore slope failures and turbidity currents revealed by most detailed monitoring yet at a fjord-head delta. Earth Planet. Sci. Lett. 450, 208-220. doi: 10.1016/j.epsl.2016.06.021

Collot, J. Y., Ratzov, G., Silva, P., Proust, J. N., Migeon, S., Hernandez, M. J., et al. (2019). The esmeraldas canyon: a helpful marker of the pliocene-pleistocene tectonic deformation of the north ecuador-southwest colombia convergent margin. Tectonics 38, 3140-3166. doi: 10.1029/2019TC005501

Contardo, X. J., Kukowski, N., and Cembrano, J. M. (2011). Material transfer and its influence on the formation of slope basins along the South Central Chilean convergent margin: insights from scaled sandbox experiments. Tectonophysics 513, 20-36. doi: 10.1016/j.tecto.2011.09.016

Contardo, X., Cembrano, J., Jensen, A., and Díaz-Naveas, J. (2008). Tectonosedimentary evolution of marine slope basins in the Chilean forearc $\left(33^{\circ} 30^{\prime}-\right.$ $36^{\circ} 50^{\prime} \mathrm{S}$ ): insights into their link with the subduction process. Tectonophysics 459, 206-218. doi: 10.1016/j.tecto.2007.12.014

D’Agostini, D. P., Bastos, A. C., Amado-Filho, G. M., Vilela, C. G., Oliveira, T. C. S., Webster, J. M., et al. (2019). Morphology and sedimentology of the shelf-upper slope transition in the Abrolhos continental shelf (east Brazilian margin). Geo Mar. Lett. 39, 117-134. doi: 10.1007/s00367-019-00562-6

Dalla Valle, G., and Gamberi, F. (2011). Pockmarks and seafloor instability in the Olbia continental slope (northeastern Sardinian margin, Tyrrhenian Sea). Mar. Geophys. Res. 32, 193-205. doi: 10.1007/s11001-011-9133-1

Damuth, J. E. (1975). Echo character of the western equatorial Atlantic floor and its relationship to the dispersal and distribution of terrigenous sediments. Mar. Geol. 18, 17-45. doi: 10.1016/0025-3227(75)90047-X

Damuth, J. E., and Gorini, M. A. (1976). The Equatorial Mid-Ocean Canyon: a relict deep-sea channel on the Brazilian continental margin. Bull. Geol. Soc. Am. $87,340-346$

de Araújo, H. A. B., Dominguez, J. M. L., Machado, A. J., and Rangel, A. G. A. N. (2018). Benthic foraminifera distribution in a deltaic clinoform (São Francisco Delta, eastern Brazil): a reference study. J. Mar. Syst. 186, 1-16. doi: 10.1016/j. jmarsys.2018.05.004

de Mahiques, M. M., Schattner, U., Lazar, M., Sumida, P. Y. G., and de Souza, L. A. P. (2017). An extensive pockmark field on the upper Atlantic margin of Southeast Brazil: spatial analysis and its relationship with salt diapirism. Heliyon 3:e00257. doi: 10.1016/j.heliyon.2017.e00257

Del-Giovannino, S. R., Dottori, M., and Martins, R. P. (2000). The north Brazil undercurrent and the wind driven hydrodynamics in Japaratuba submarine canyon, Brazil. Brazilian J. Oceanogr. 1, 3-6.

do Nascimento Silva, L. L., Gomes, M. P., and Vital, H. (2018). The Açu Reef morphology, distribution, and inter reef sedimentation on the outer shelf of the NE Brazil equatorial margin. Cont. Shelf Res. 160, 10-22. doi: 10.1016/j.csr. 2018.03.011

Dominguez, J. M. L., Da Silva, R. P., Nunes, A. S., and Freire, A. F. M. (2013). The narrow, shallow, low-accommodation shelf of central Brazil: sedimentology, evolution, and human uses. Geomorphology 203, 46-59. doi: 10.1016/j.geomorph.2013.07.004

Eichler, P. P. B., do Nascimento Silva, L. L., de Andrade, A. U., de Oliveira Martins, J. F., de Farias, C. L. C., Moura, D. S., et al. (2019). Organically enriched sediments and foraminiferal species from the Açu Reef, indicators of upwelling in NE Brazil? Mar. Geol. 417:106016. doi: 10.1016/j.margeo.2019.106016

Embley, R. W., Ewing, J. I., and Ewing, M. (1970). The Vidal deep-sea Channel and its relationship to the Demerara and Barracuda Abyssal plains. Deep. Res. Oceanogr. Abstr. 17, 539-552. doi: 10.1016/0011-7471(70)90066-5

Ercilla, G., Schwenk, T., Bozzano, G., Spiess, V., Violante, R., Estrada, F., et al. (2019). Cenozoic sedimentary history of the northern Argentine continental slope, off Bahia Blanca, the location of the Ewing Terrace: palaeogeodynamic and palaeoceanographic implications. Mar. Geol. 417:106028. doi: 10.1016/j. margeo.2019.106028

Escobar, N. F. C., Dominguez, J. M. L., Zucchi, M., do, R., de Azevedo, A. E. G., Rangel, A. G., et al. (2019). Organic matter in the deltaic clinoform of the São Francisco River (Eastern Brazil). Geo-Marine Lett. 40, 879-895. doi: 10.1007/ s00367-019-00607-w

Esteban, F., Tassone, A., Menichetti, M., and Lodolo, E. (2017). Application of slope maps as a complement of bathymetry: example from the SW Atlantic. Mar. Geod. 40, 57-71. doi: 10.1080/01490419.2016.1269033

European Union. (2014). Directive 2014/89/EU of the European Parliment and of the Council of 23 July 2014 establishing a framework for maritime spatial planning. Off. J. Eur. Union 2014, 135-145.

Faugères, J. C., Gonthier, E., Griboulard, R., and Masse, L. (1993). Quaternary sandy deposits and canyons on the Venezuelan margin and south Barbados accretionary prism. Mar. Geol. 110, 115-142. doi: 10.1016/0025-3227(93) 90109-9

Fernandez-Arcaya, U., Ramirez-Llodra, E., Aguzzi, J., Allcock, A. L., Davies, J. S., Dissanayake, A., et al. (2017). Ecological role of submarine canyonsand need for canyon conservation: a review. Front. Mar. Sci. 4:5. doi: 10.3389/fmars.2017. 00005

Fildani, A. (2017). Submarine canyons: a brief review looking forward. Geology 45 , 383-384. doi: 10.1130/focus042017.1

Flores, J. N., Brogger, M. I., and Penchaszadeh, P. E. (2019). Reproduction and development of the brooding sea urchin Austrocidaris canaliculata from deepsea off Argentina. Deep. Res. Part I Oceanogr. Res. Pap. 143, 35-42. doi: 10.1016/ j.dsr.2018.11.012

Franco-Fraguas, P., Burone, L., Mahiques, M., Ortega, L., Urien, C., Muñoz, A., et al. (2014). Hydrodynamic and geomorphological controls on surface sedimentation at the Subtropical Shelf Front / Brazil-Malvinas Confluence transition off Uruguay (Southwestern Atlantic Continental Margin). Mar. Geol. 349, 24-36. doi: 10.1016/j.margeo.2013.12.010

Gao, S., and Collins, M. B. (2014). Holocene sedimentary systems on continental shelves. Mar. Geol. 352, 268-294. doi: 10.1016/j.margeo.2014.03.021

Geersen, J., Völker, D., Behrmann, J. H., Reichert, C., and Krastel, S. (2011). Pleistocene giant slope failures offshore Arauco Peninsula, Southern Chile. J. Geol. Soc. London 168, 1237-1248. doi: 10.1144/0016-76492011-027

Geist, E. L., and Lynett, P. J. (2011). Source processes for the probabilistic assessment of tsunami hazards. Oceanography 27, 86-93. doi: 10.5670/oceanog. 2014.43

Golden, J. S., Virdin, J., Nowacek, D., Halpin, P., Bennear, L., and Patil, P. G. (2017). Making sure the blue economy is green. Nat. Ecol. Evol. 1:17. doi: 10.1038/s41559-016-0017

Gomes, M. P., Vital, H., Stattegger, K., and Schwarzer, K. (2016). Bedrock control on the assu incised valley morphology and sedimentation in the brazilian equatorial shelf. Int. J. Sediment Res. 31, 181-193. doi: 10.1016/j.ijsrc.2015.04. 002

Gorini, C., Haq, B. U., dos Reis, A. T., Silva, C. G., Cruz, A., Soares, E., et al. (2014). Late neogene sequence stratigraphic evolution of the Foz do Amazonas Basin, Brazil. Terra Nov. 26, 179-185. doi: 10.1111/ter.12083

Gruetzner, J., Uenzelmann-Neben, G., and Franke, D. (2012). Variations in sediment transport at the central Argentine continental margin during the Cenozoic. Geochem. Geophys. Geosyst. 13, 1-15. doi: 10.1029/2012GC004266

Gruetzner, J., Uenzelmann-Neben, G., and Franke, D. (2016). Evolution of the northern Argentine margin during the Cenozoic controlled by bottom current dynamics and gravitational processes. Geochem. Geophys. Geosyst. 17, 45174533. doi: 10.1002/2015GC006171.Received

Gu, F., Chiessi, C. M., Zonneveld, K. A. F., and Behling, H. (2019). Shifts of the Brazil-Falklands/malvinas confluence in the western south atlantic during the latest pleistocene-holocene inferred from dinoflagellate cysts. Palynology 43, 483-493. doi: 10.1080/01916122.2018.1470116 
Hagen, R. A., Bergersen, D. D., Moberly, R., and Coulbourn, W. T. (1994). Morphology of a large meandering submarine canyon system on the Peru-Chile forearc. Mar. Geol. 119, 7-38. doi: 10.1016/0025-3227(94)90138-4

Hagen, R. A., Vergara, H., and Naar, D. F. (1996). Morphology of San Antonio submarine canyon on the central Chile forearc. Mar. Geol. 129, 197-205. doi: 10.1016/0025-3227(96)83345-7

Hanebuth, T. J. J., Bender, V. B., and Nagai, R. H. (2019). Sediment Export Dynamics Reflecting the Holocene Hydrodynamic Variability of a High-Energy Continental Shelf System (Southeastern South America). J. Sediment. Environ. 4, 312-331. doi: 10.12957/jse.2019.45616

Harris, P. T. (2020). The fate of microplastic in marine sedimentary environments: a review and synthesis. Mar. Pollut. Bull. 158:111398. doi: 10.1016/j.marpolbul. 2020.111398

Hasegawa, K., Fujiwara, Y., Okutani, T., Sumida, P. Y. G., Kawato, M., and Kitazato, H. (2019). A new gastropod associated with a deep-sea whale carcass from São Paulo Ridge, Southwest Atlantic. Zootaxa 4568, 347-356. doi: 10.11646/ zootaxa.4568.2.9

Hatje, V., Andrade, R. L. B., de Oliveira, C. C., Polejack, A., and Gxaba, T. (2021). Pollutants in the south atlantic ocean: sources, knowledge gaps and perspectives for the decade of ocean science. Front. Mar. Sci. 8:644569. doi: 10.3389/fmars. 2021.644569

He, Y., Zhong, G., Wang, L., and Kuang, Z. (2014). Characteristics and occurrence of submarine canyon-associated landslides in the middle of the northern continental slope, South China Sea. Mar. Pet. Geol. 57, 546-560. doi: 10.1016/j. marpetgeo.2014.07.003

Heberer, B., Behrmann, J. H., and Rahn, M. K. (2011). Source-to-sink relationships along the South-Central Chilean margin: evidence from detrital apatite fissiontrack analysis. Basin Res. 23, 551-570. doi: 10.1111/j.1365-2117.2011.00504. $\mathrm{x}$

Heberer, B., Röser, G., Behrmann, J. H., Rahn, M., and Kopf, A. (2010). Holocene sediments from the Southern Chile trench: a record of active margin magmatism, tectonics and palaeoseismicity. J. Geol. Soc. London 167, 539-553. doi: 10.1144/0016-76492009-015

Heiniö, P., and Davies, R. J. (2009). Trails of depressions and sediment waves along submarine channels on the continental margin of Espirito Santo Basin, Brazil. Bull. Geol. Soc. Am. 121, 698-711. doi: 10.1130/B26190.1

Hernández-Molina, F. J., Serra, N., Stow, D. A. V., Llave, E., Ercilla, G., and van Rooij, D. (2011). Along-slope oceanographic processes and sedimentary products around the Iberian margin. Geo Mar. Lett. 31, 315-341. doi: 10.1007/ s00367-011-0242-2

Heymans, J. J., Bundy, A., Christensen, V., Coll, M., de Mutsert, K., Fulton, E. A., et al. (2020). The ocean decade: a true ecosystem modeling challenge. Front. Mar. Sci. 7:554573. doi: 10.3389/fmars.2020.554573

Hickey, B. M. (1997). The response of a steep-sided, narrow canyon to timevariable wind forcing. J. Phys. Oceanogr. 27, 697.

Hübscher, C., Figueiredo, J. G., Kruse, L., and Spieß, V. (2002). High-resolution analysis of the deposition pattern on the Amazon sub-aquatic delta and outer continental shelf. Mar. Geophys. Res. 23, 209-222. doi: 10.1023/A: 1023603221876

IOC-UNESCO (2021). Ocean Decade Implementation Plan. IOC Ocean Decad. Ser. 139-142.

Idárraga-García, J., and León, H. (2019). Unraveling the underwater morphological features of Roncador Bank, archipelago of San Andres, Providencia and Santa Catalina (Colombian Caribbean). Front. Mar. Sci. 6:77. doi: 10.3389/fmars. 2019.00077

Idárraga-García, J., Masson, D. G., García, J., León, H., and Vargas, C. A. (2019). Architecture and development of the Magdalena Submarine Fan (southwestern Caribbean). Mar. Geol. 414, 18-33. doi: 10.1016/j.margeo.2019.05.005

Ioualalen, M., Ratzov, G., Collot, J. Y., and Sanclemente, E. (2011). The tsunami signature on a submerged promontory: the case study of the Atacames Promontory, Ecuador. Geophys. J. Int. 184, 680-688. doi: 10.1111/j.1365-246X. 2010.04878.x

Isola, J. I., Ormazabal, J. P., Flores, G., Arismendi, S., Druet, M., Muñoz, A., et al. (2020). Tectonic and structural controls on Neogene fluid release in the Patagonian Continental Margin. Mar. Pet. Geol. 115:104246. doi: 10.1016/j. marpetgeo.2020.104246

Ivar do Sul, J. A., Costa, M. F., Barletta, M., and Cysneiros, F. J. A. (2013). Pelagic microplastics around an archipelago of the Equatorial Atlantic. Mar. Pollut. Bull. 75, 305-309. doi: 10.1016/j.marpolbul.2013.07.040
Jara-Muñoz, J., Melnick, D., Zambrano, P., Rietbrock, A., González, J., Argandoña, B., et al. (2017). Quantifying offshore fore-arc deformation and splay-fault slip using drowned Pleistocene shorelines, Arauco Bay, Chile. J. Geophys. Res. Solid Earth 122, 4529-4558. doi: 10.1002/2016JB013339

Jegou, I., Savoye, B., Pirmez, C., and Droz, L. (2008). Channel-mouth lobe complex of the recent Amazon Fan: the missing piece. Mar. Geol. 252, 62-77. doi: 10.1016/j.margeo.2008.03.004

Johnstone, P., and McLeish, C. (2020). World wars and the age of oil: exploring directionality in deep energy transitions. Energy Res. Soc. Sci. 69:101732. doi: $10.1016 /$ j.erss.2020.101732

Kane, I. A., and Clare, M. A. (2019). Dispersion, accumulation, and the ultimate fate of microplastics in deep-marine environments: a review and future directions. Front. Earth Sci. 7:80. doi: 10.3389/feart.2019.00080

Katsanevakis, S., Stelzenmüller, V., South, A., Sørensen, T. K., Jones, P. J. S., Kerr, S., et al. (2011). Ecosystem-based marine spatial management: review of concepts, policies, tools, and critical issues. Ocean Coast. Manag. 54, 807-820. doi: 10.1016/j.ocecoaman.2011.09.002

Kelley, D. S., Delaney, J. R., and Juniper, S. K. (2014). Establishing a new era of submarine volcanic observatories: cabling axial seamount and the endeavour segment of the juan de fuca ridge. Mar. Geol. 352, 426-450. doi: 10.1016/j. margeo.2014.03.010

Kerry, J. C., Gary, D. H., and Robert, L. L. (2008). "Modern deepwater site investigation: getting it right the first time," in Proceedings of the Annual Offshore Technol. Conference, Houston, TX, 5-8.

Kokot, R. R. (2004). Erosión en la costa patagónica por cambio climático. Rev. Asoc. Geol. Argentina 59, 715-726.

Krastel, S., Wefer, G., Hanebuth, T. J. J., Antobreh, A. A., Freudenthal, T., Preu, B., et al. (2011). Sediment dynamics and geohazards off Uruguay and the de la Plata River region (northern Argentina and Uruguay). Geo Mar. Lett. 31, 271-283. doi: 10.1007/s00367-011-0232-4

Landaeta, M. F., Veas, R., Letelier, J., and Castro, L. R. (2008). Larval fish assemblages off central Chile upwelling ecosystem. Rev. Biol. Mar. Oceanogr. 43, 569-584. doi: 10.4067/s0718-19572008000300016

Lastras, G., Acosta, J., Muñoz, A., and Canals, M. (2011). Submarine canyon formation and evolution in the Argentine Continental Margin between $44^{\circ} 30^{\prime} \mathrm{S}$ and $48^{\circ}$ S. Geomorphology 128, 116-136. doi: 10.1016/j.geomorph.2010.12.027

Lauretta, D., and Martinez, M. I. (2019). Corallimorpharians (Anthozoa: Corallimorpharia) from the Argentinean Sea. Zootaxa 4688, 249-263. doi: 10. 11646/zootaxa.4688.2.5

Lauretta, D., and Penchaszadeh, P. E. (2017). Gigantic oocytes in the deep sea black coral Dendrobathypathes grandis (Antipatharia) from the Mar del Plata submarine canyon area (southwestern Atlantic). Deep. Res. Part I Oceanogr. Res. Pap. 128, 109-114. doi: 10.1016/j.dsr.2017.08.011

Laursen, J., Scholl, D. W., and von Huene, R. (2002). Neotectonic deformation of the central Chile margin: deepwater forearc basin formation in response to hot spot ridge and seamount subduction. Tectonics 21, 2-1. doi: 10.1029/ 2001tc901023

Lavagnino, A. C., Bastos, A. C., Amado Filho, G. M., de Moraes, F. C., Araujo, L. S., and de Moura, R. L. (2020). Geomorphometric seabed classification and potential megahabitat distribution in the amazon continental margin. Front. Mar. Sci. 7:190. doi: 10.3389/fmars.2020.00190

Lee, K., Armsworthy, S. L., Cobanli, S. E., Cochrane, N. A., Cranford, P. J., Drozdowski, A., et al. (2011). Consideration of the Potential Impacts on the Marine Environment Associated with Offshore Petroleum Exploration and Development Activities. Ottawa, ON: Fisheries and Oceans Canada.

Leite, L. M., Dias, J. M., Carvalho, J. M. B., and Klein, A. H. F. (2011). Hydrodynamic study of bay beaches - a case study of Itapocorói Bay, Brazil. J. Coast. Res. 1086-1090.

Leth, O., and Middleton, J. F. (2004). A mechanism for enhanced upwelling off central chile: eddy advection. J. Geophys. Res. Ocean. 109:C12020. doi: 10.1029/ 2003JC002129

Leynaud, D., and Sultan, N. (2010). 3-D slope stability analysis: a probability approach applied to the nice slope (SE France). Mar. Geol. 269, 89-106. doi: 10.1016/j.margeo.2009.12.002

Li, C. (1995). Forearc structures and tectonics in the southern peru-northern chile continental Margin. Mar. Geophys. Res. 17, 97-113. doi: 10.1007/BF01268052

Lima, J. A. M., Moller, O. O., Viana, A. R., and Piovesan, R. (2007). Hydrodynamic modelling of bottom currents and sediment transport in the Canyon São Tomé 
(Brazil). Geol. Soc. Spec. Publ. 276, 329-342. doi: 10.1144/GSL.SP.2007.276.01. 16

Lima, K. T. P., and Dias, C. A. (2008). Characterization of turbidites from the Urucutuca Formation of the Almada Basin, Bahia, Brazil, using seismic and petrophysical well log data. Pet. Geosci. 14, 167-182. doi: 10.1144/1354-079308735

López-Ramos, E. (2016). Hydrocarbon generation models along the basal detachment of the andean subduction zone in northern Ecuador to southern Colombia. Cienc. Tecnol. Futur. 6, 25-52.

Lorenzoni, L., Benitez-Nelson, C. R., Thunell, R. C., Hollander, D., Varela, R., Astor, Y., et al. (2012). Potential role of event-driven sediment transport on sediment accumulation in the Cariaco Basin. Venezuela. Mar. Geol. 307-310, 105-110. doi: 10.1016/j.margeo.2011.12.009

Mansurbeg, H., De Ros, L. F., Morad, S., Ketzer, J. M., El-Ghali, M. A. K., Caja, M. A., et al. (2012). Meteoric-water diagenesis in late Cretaceous canyon-fill turbidite reservoirs from the Espírito Santo Basin, eastern Brazil. Mar. Pet. Geol. 37, 7-26. doi: 10.1016/j.marpetgeo.2012.03.009

Martínez, C., Rojas, O., Aránguiz, R., Belmonte, A., Altamirano, Á, and Flores, P. (2012). Riesgo de tsunami en caleta tubul, región del biobío: escenarios extremos y transformaciones territoriales posterremoto. Rev. Geogr. Norte Gd. 55, 85-106. doi: 10.4067/s0718-34022012000300006

Martinez, M. I., Solís-Marín, F. A., and Penchaszadeh, P. E. (2019). First report of Paelopatides (Synallactida, Synallactidae) for the SW Atlantic, with description of a new species from the deep-sea off Argentina. Zool. Anz. 278, 21-27. doi: 10.1016/j.jcz.2018.10.010

Mason, C. C., Romans, B. W., Stockli, D. F., Mapes, R. W., and Fildani, A. (2019). Detrital zircons reveal sea-level and hydroclimate controls on Amazon River to deep-sea fan sediment transfer. Geology 47, 563-567. doi: 10.1130/G45852.1

Mayer, I., Zhou, Q., Lo, J., Abspoel, L., Keijser, X., Olsen, E., et al. (2013). Integrated, ecosystem-based marine spatial planning: design and results of a game-based, quasi-experiment. Ocean Coast. Manag. 82, 7-26. doi: 10.1016/j.ocecoaman. 2013.04.006

Medina, G., Castro, L., and Pantoja, S. (2014). Fatty acids in merluccius australis tissues, a comparison between females from inshore and offshore spawning areas in the chilean patagonia. Fish. Res. 160, 41-49. doi: 10.1016/j.fishres.2013. 11.005

Meleddu, A., Deiana, G., Paliaga, E. M., Todde, S., and Orrù, P. E. (2016). Continental shelf and slope geomorphology: marine slumping and hyperpycnal flows (Sardinian Southern Continental Margin, Italy). Geogr. Fis. Din. Quat. 39, 183-192. doi: 10.4461/GFDQ2016.39.17

Michaud, F., Proust, J. N., Collot, J. Y., Lebrun, J. F., Witt, C., Ratzov, G., et al. (2015). Quaternary sedimentation and active faulting along the Ecuadorian shelf: preliminary results of the ATACAMES Cruise (2012). Mar. Geophys. Res. 36, 81-98. doi: 10.1007/s11001-014-9231-y

Molina, V., Farías, L., Graco, M., Rivera, C., Pinto, L., and Gallardo, V. A. (2004). Benthic nitrogen regeneration under oxygen and organic matter spatial variability off Concepción $\left(\sim 36^{\circ}\right)$, central Chile. Deep. Res. Part II Top. Stud. Oceanogr. 51, 2507-2522. doi: 10.1016/j.dsr2.2004.08.014

Monteiro, R. C. P., Do Sul, J. A. I., and Costa, M. F. (2020). Small microplastics on beaches of fernando de noronha island, tropical atlantic ocean. Ocean Coast. Res. 68:e20235. doi: 10.1590/S2675-28242020068235

Monteiro, R. C. P., Ivar do Sul, J. A., and Costa, M. F. (2018). Plastic pollution in islands of the Atlantic Ocean. Environ. Pollut. 238, 103-110. doi: 10.1016/j. envpol.2018.01.096

Montero, P., Daneri, G., Cuevas, L. A., González, H. E., Jacob, B., Lizárraga, L., et al. (2007). Productivity cycles in the coastal upwelling area off concepción: the importance of diatoms and bacterioplankton in the organic carbon flux. Prog. Oceanogr. 75, 518-530. doi: 10.1016/j.pocean.2007.08.013

Moscardelli, L., and Wood, L. (2008). New classification system for mass transport complexes in offshore Trinidad. Basin Res. 20, 73-98. doi: 10.1111/j.1365-2117. 2007.00340.x

Moscardelli, L., Wood, L. J., and Dunlap, D. B. (2012). Shelf-edge deltas along structurally complex margins: a case study from eastern offshore Trinidad. Am. Assoc. Pet. Geol. Bull. 96, 1483-1522. doi: 10.1306/01241211046

Muñoz, P., Lange, C. B., Gutiérrez, D., Hebbeln, D., Salamanca, M. A., Dezileau, L., et al. (2004). Recent sedimentation and mass accumulation rates based on $210 \mathrm{~Pb}$ along the Peru-Chile continental margin. Deep. Res. Part II Top. Stud. Oceanogr. 51, 2523-2541. doi: 10.1016/j.dsr2.2004.08.015
Muñoz, P., Sellanes, J., Lange, C., Palma, M., and Salamanca, M. A. (2007). Temporal variability of $210 \mathrm{~Pb}$ fluxes and bioturbation in shelf sediments beneath the high primary production area off concepción, central-southern Chile ( $36^{\circ}$ S). Prog. Oceanogr. 75, 586-602. doi: 10.1016/j.pocean.2007.08.015

Nunn, P. D., and Pastorizo, R. (2007). Geological histories and geohazard potential of Pacific Islands illuminated by myths. Geol. Soc. London Spec. Publ. 273, 143-163. doi: 10.1144/GSL.SP.2007.273.01.13

Penchaszadeh, P. E., Atencio, M., Martinez, M. I., and Pastorino, G. (2016). Giant egg capsules and hatchlings in a deep-sea moon snail (Naticidae) from a southwestern Atlantic Canyon. Mar. Biol. 163:209.

Penchaszadeh, P. E., Teso, V., and Pastorino, G. (2017). Spawn in two deepsea volute gastropods (Neogastropoda: Volutidae) from southwestern Atlantic waters. Deep. Res. Part I Oceanogr. Res. Pap. 130, 55-62. doi: 10.1016/j.dsr.2017. 10.011

Pereira, E., Roccatagliata, D., and Doti, B. L. (2019). Xiphoarcturus - a new genus and two new species of the family Antarcturidae (Isopoda: Valvifera) from the Mar del Plata submarine canyon and its phylogenetic relationships. Arthropod. Syst. Phylogeny 77, 303-323. doi: 10.26049/ASP77-2-2019-07

Pierdomenico, M., Casalbore, D., and Chiocci, F. L. (2019). Massive benthic litter funnelled to deep sea by flash-flood generated hyperpycnal flows. Sci. Rep. 9:5330. doi: 10.1038/s41598-019-41816-8

Pimento, F., Garvine, R. W., and Miinchow, A. (2008). Observations of coastal upwelling off Uruguay downshelf of the Plata estuary, South America. J. Mar. Res. 66, 835-872. doi: 10.1357/002224008788064577

Polejack, A. (2021). The importance of ocean science diplomacy for ocean affairs, global sustainability, and the un decade of ocean science. Front. Mar. Sci. 8:664066. doi: $10.3389 /$ fmars.2021.664066

Polejack, A., and Coelho, L. F. (2021). Ocean science diplomacy can be a game changer to promote the access to marine technology in latin america and the caribbean. Front. Res. Metrics Anal. 6:34-36. doi: 10.3389/frma.2021.637127

Ratzov, G., Collot, J. Y., Sosson, M., and Migeon, S. (2010). Mass-transport deposits in the northern Ecuador subduction trench: result of frontal erosion over multiple seismic cycles. Earth Planet. Sci. Lett. 296, 89-102. doi: 10.1016/j.epsl. 2010.04.048

Ratzov, G., Sosson, M., Collot, J. Y., and Migeon, S. (2012). Late quaternary geomorphologic evolution of submarine canyons as a marker of active deformation on convergent margins: the example of the South Colombian margin. Mar. Geol. 315-318, 77-97. doi: 10.1016/j.margeo.2012.05.005

Restrepo-Correa, I. C., and Ojeda, G. Y. (2010). Geologic controls on the morphology of La Aguja submarine canyon. J. South Am. Earth Sci. 29, 861-870. doi: 10.1016/j.jsames.2010.07.001

Riedinger, N., Brunner, B., Krastel, S., Arnold, G. L., Wehrmann, L. M., Formolo, M. J., et al. (2017). Sulfur cycling in an iron oxide-dominated, dynamic marine depositional system: the argentine continental margin. Front. Earth Sci. 5:33. doi: $10.3389 /$ feart.2017.00033

Robertson, C. M., Demopoulos, A. W. J., Bourque, J. R., Mienis, F., Duineveld, G. C. A., Lavaleye, M. S. S., et al. (2020). Submarine canyons influence macrofaunal diversity and density patterns in the deep-sea benthos. Deep. Res. Part I Oceanogr. Res. Pap. 159:103249. doi: 10.1016/j.dsr.2020.103249

Rodrigo, C., González-Fernández, A., and Vera, E. (2009). Variability of the bottom-simulating reflector (BSR) and its association with tectonic structures in the Chilean margin between Arauco Gulf $\left(37^{\circ} \mathrm{S}\right)$ and Valdivia $\left(40^{\circ} \mathrm{S}\right)$. Mar. Geophys. Res. 30, 1-19. doi: 10.1007/s11001-009-9064-2

Rojas, P. M., and Landaeta, M. F. (2014). Retención de larvas de peces asociada a una batimetría abrupta en Bahía Mejillones (norte de Chile) durante eventos de surgencia costera. Lat. Am. J. Aquat. Res. 42, 989-1008. doi: 10.3856/vol42issue5-fulltext- 6

Rolin, J.-F., Bompais, X., and Le Guen, Y. (2013). “Long term subsea monitoring of academic research sites and oil and gas industrial sites: common standards and interoperability?", in Procceedings of the 2013 MTS/IEEE Ocean. - Bergen, (IEEE: Bergen), 1-4. doi: 10.1109/OCEANS-Bergen.2013.6608149

Rovira, D. P. T., Gomes, M. P., and Longo, G. O. (2019). Underwater valley at the continental shelf structures benthic and fish assemblages of biogenic reefs. Estuar. Coast. Shelf Sci. 224, 245-252. doi: 10.1016/j.ecss.2019. 05.001

Ryabinin, V., Barbière, J., Haugan, P., Kullenberg, G., Smith, N., McLean, C., et al. (2019). The UN decade of ocean science for sustainable development. Front. Mar. Sci. 6:470. doi: 10.3389/fmars.2019.00470 
Sánchez, N., Pastorino, G., and Penchaszadeh, P. E. (2018). Giant eggs in the gastropod Aforia obesa (Conoidea: Cochlespiridae) in Southwestern Atlantic deep-waters. Zool. Anz. 276, 94-99. doi: 10.1016/j.jcz.2018.07.006

Santora, J. A., Zeno, R., Dorman, J. G., and Sydeman, W. J. (2018). Submarine canyons represent an essential habitat network for krill hotspots in a Large Marine Ecosystem /631/158 /704/829 article. Sci. Rep. 8:7579.

Schejter, L., López Gappa, J., and Bremec, C. S. (2014). Epibiotic relationships on Zygochlamys patagonica (Mollusca, Bivalvia, Pectinidae) increase biodiversity in a submarine canyon in Argentina. Deep. Res. Part II Top. Stud. Oceanogr. 104, 252-258. doi: 10.1016/j.dsr2.2013.10.010

Schejter, L., Rimondino, C., Chiesa, I., Díaz de Astarloa, J. M., Doti, B., Elías, R., et al. (2016). Namuncurá marine protected area: an oceanic hot spot of benthic biodiversity at Burdwood Bank, Argentina. Polar Biol. 39, 2373-2386. doi: 10.1007/s00300-016-1913-2

Schubert, C. (1982). Origin of cariaco basin, southern caribbean sea. Mar. Geol. 47, 345-360. doi: 10.1016/0025-3227(82)90076-7

Siegwald, J., Pastorino, G., Oskars, T., and Malaquias, M. A. E. (2020). A new species of the deep-sea genus Scaphander (Gastropoda, Cephalaspidea) from the Mar del Plata submarine canyon off Argentina. Bull. Mar. Sci. 96, 111-126. doi: 10.5343/bms.2019.0069

Smith-Godfrey, S. (2016). Defining the blue economy. Marit. Aff. 12, 58-64. doi: 10.1080/09733159.2016.1175131

Sobarzo, M., and Djurfeldt, L. (2004). Coastal upwelling process on a continental shelf limited by submarine canyons, Concepción, central Chile. J. Geophys. Res. Ocean. 109, 1-20. doi: 10.1029/2004JC002350

Sobarzo, M., Bravo, L., and Moffat, C. (2010). Diurnal-period, wind-forced ocean variability on the inner shelf off Concepción. Chile. Cont. Shelf Res. 30, 20432056. doi: 10.1016/j.csr.2010.10.004

Sobarzo, M., Bravo, L., Donoso, D., Garcés-Vargas, J., and Schneider, W. (2007). Coastal upwelling and seasonal cycles that influence the water column over the continental shelf off central Chile. Prog. Oceanogr. 75, 363-382. doi: 10.1016/j. pocean.2007.08.022

Sobarzo, M., Figueroa, M., and Djurfeldt, L. (2001). Upwelling of subsurface water into the rim of the Biobío submarine canyon as a response to surface winds. Cont. Shelf Res. 21, 279-299. doi: 10.1016/S0278-4343(00)00082-0

Sobarzo, M., Saldías, G. S., Tapia, F. J., Bravo, L., and Moffat, C. (2016). On subsurface cooling associated with the Biobio River Canyon (Chile). J. Geophys. Res. Ocean. 175:238. doi: 10.1038/175238c0

Solheim, A., Forsberg, C., and Yang, S. (2007). The role of geological setting and depositional history in offshore slope instability. Paper presented at the Offshore Technology Conference, Houston, TX.

Steenbeek, J., Romagnoni, G., Bentley, J. W., Heymans, J. J., Serpetti, N., Gonçalves, M., et al. (2020). Combining ecosystem modeling with serious gaming in support of transboundary maritime spatial planning. Ecol. Soc. 25, 1-24. doi: 10.5751/ES-11580-250221

Stow, D., Brackenridge, R., and Toulmin, S. J. (2012). Geohazards and ocean hazards in deepwater: overview and methods of assessment. Paper presented at the Offshore Technology Conference, Houston, TX, doi: 10.4043/23697-MS

Ternes, C. F., de Macedo Dias, G. T., and Dias, M. S. (2020). Geohabitats characterization in areas of dredge sediment disposals on Rio de Janeiro continental shelf, adjacent to Guanabara Bay: Brazil. Geo Mar. Lett. 40, 10151030. doi: 10.1007/s00367-019-00620-Z

Teso, V., Urteaga, D., and Pastorino, G. (2019). Assemblages of certain benthic molluscs along the southwestern Atlantic: from subtidal to deep sea. BMC Ecol. 19:49. doi: 10.1186/s12898-019-0263-7

Testa, G., Masotti, I., and Farías, L. (2018). Temporal variability in net primary production in an upwelling area off central Chile (36 ${ }^{\circ}$ ). Front. Mar. Sci. 5:179. doi: $10.3389 /$ fmars.2018.00179

Thierer, P. O., Flueh, E. R., Kopp, H., Tilmann, F., Comte, D., and Contreras, S. (2005). Local earthquake monitoring offshore Valparaiso, Chile. Neues Jahrb. Geol. Palaontol. Abh. 236, 173-183. doi: 10.1127/njgpa/236/2005/173

Tréhu, A. M., de Moor, A., Madrid, J. M., Sáez, M., Chadwell, C. D., OrtegaCulaciati, F., et al. (2020). Post-seismic response of the outer accretionary prism after the 2010 Maule earthquake, Chile. Geosphere 16, 13-32. doi: 10.1130/ GES02102.1

Tubau, X., Canals, M., Lastras, G., Rayo, X., Rivera, J., and Amblas, D. (2015). Marine litter on the floor of deep submarine canyons of the Northwestern Mediterranean Sea: the role of hydrodynamic processes. Prog. Oceanogr. 134, 379-403. doi: 10.1016/j.pocean.2015.03.013
Uddin, S., Fowler, S. W., Uddin, M. F., Behbehani, M., and Naji, A. (2021). A review of microplastic distribution in sediment profiles. Mar. Pollut. Bull. 163, 111973. doi: 10.1016/j.marpolbul.2021.111973

Valle-Levinson, A., and Moraga-Opazo, J. (2006). Observations of bipolar residual circulation in two equatorward-facing semiarid bays. Cont. Shelf Res. 26, 179193. doi: 10.1016/j.csr.2005.10.002

Valle-Levinson, A., Atkinson, L. P., Figueroa, D., and Castro, L. (2003). Flow induced by upwelling winds in an equatorward facing bay: Gulf of Arauco, Chile. J. Geophys. Res. C Ocean. 108:3054. doi: 10.1029/2001jc001272

Vargas, C. A., Valenzuela, G. S., Núñez, S. P., and Arcos, D. F. (1997). Role of oceanographic and topographic factors in the retention of hake (Merluccius gayi gayi Guichenot, 1848) larvae in the upwelling system off central-southern Chile. Arch. Fish. Mar. Res. 45, 201-222.

Vazquez, D. M., Mabragaña, E., Gabbanelli, V., and Díaz de Astarloa, J. M. (2016). Exploring nursery sites for oviparous chondrichthyans in the Southwest Atlantic ( $36^{\circ} \mathrm{S}-41^{\circ}$ S). Mar. Biol. Res. 12, 715-725. doi: 10.1080/17451000.2016. 1203948

Vergara, H. (1997). The Valparaiso Basin: a morphotectonic and sedimentological background (La cuenca de Valparaiso: antecedentes morfotectonicos y sedimentologicos). Rev. Biol. Mar. 12:1456.

Vergara, O. A., Echevín, V., Sepúlveda, H. H., and Quiñones, R. A. (2017). Controlling factors of the seasonal variability of productivity in the southern Humboldt Current System $\left(30-40^{\circ} \mathrm{S}\right)$ : a biophysical modeling approach. Cont. Shelf Res. 148, 89-103. doi: 10.1016/j.csr.2017.08.013

Viana, A. R., Faugères, J. C., Kowsmann, R. O., Lima, J. A. M., Caddah, L. F. G., and Rizzo, J. G. (1998). Hydrology, morphology and sedimentology of the Campos continental margin, offshore Brazil. Sediment. Geol. 115, 133-157. doi: 10.1016/S0037-0738(97)00090-0

Violante, R. A., Paterlini, C. M., Costa, I. P., Hernández-Molina, F. J., Segovia, L. M., Cavallotto, J. L., et al. (2010). Sismoestratigrafia y evolucion geomorfologica del talud continental adyacente al litoral del este bonaerense, argentina. Lat. Am. J. Sedimentol. Basin Anal. 17, 33-62.

Voigt, I., Henrich, R., Preu, B. M., Piola, A. R., Hanebuth, T. J. J., Schwenk, T., et al. (2013). A submarine canyon as a climate archive - Interaction of the antarctic intermediate water with the mar del plata canyon (southwest atlantic). Mar. Geol. 341, 46-57. doi: 10.1016/j.margeo.2013.05.002

Völker, D., Geersen, J., Contreras-Reyes, E., and Reichert, C. (2013). Sedimentary fill of the Chile Trench $\left(32-46^{\circ} \mathrm{S}\right)$ : volumetric distribution and causal factors. J. Geol. Soc. London 170, 723-736. doi: 10.1144/jgs2012-119

Volker, D., Geersen, J., Contreras-Reyes, E., Sellanes, J., Pantoja, S., Rabbel, W., et al. (2012). Morphology \& geology of continental shelf and upper slope of southern Central (33S-43S). Int. J. Earth Sci. 103, $1765-1787$.

Völker, D., Weinrebe, W., Behrmann, J. H., Bialas, J., and Klaeschen, D. (2009). Mass wasting at the base of the south central Chilean continental margin: the Reloca Slide. Adv. Geosci. 22, 155-167. doi: 10.5194/adgeo-22-1552009

Voyer, M., Quirk, G., McIlgorm, A., and Azmi, K. (2018). Shades of blue: what do competing interpretations of the blue economy mean for oceans governance? J. Environ. Policy Plan. 20, 595-616. doi: 10.1080/1523908X.2018.1473153

Warratz, G., Henrich, R., Voigt, I., Chiessi, C. M., Kuhn, G., and Lantzsch, H. (2017). Deglacial changes in the strength of deep southern component water and sediment supply at the Argentine continental margin. Paleoceanography 32, 796-812. doi: 10.1002/2016PA003079

Warratz, G., Schwenk, T., Voigt, I., Bozzano, G., Henrich, R., Violante, R., et al. (2019). Interaction of a deep-sea current with a blind submarine canyon (Mar del Plata Canyon, Argentina). Mar. Geol. 417:106002. doi: 10.1016/j.margeo. 2019.106002

Yamashita, C., De Mello, E., Sousa, S. H., Kaminski, M. A., and De Araujo, B. D. (2018). Description, distribution and ecology of living (rose Bengal stained) Eggerelloides camaraensis n. sp. Micropaleontology 64, 515-525.

Yannicelli, B., Castro, L. R., Valle-Levinson, A., Atkinson, L., and Figueroa, D. (2006). Vertical distribution of decapod larvae in the entrance of an equatorward facing bay of central Chile: implications for transport. J. Plankton Res. 28, 19-37. doi: 10.1093/plankt/fbi098

Yannicelli, B., Castro, L., Parada, C., Schneider, W., Colas, F., and Donoso, D. (2012). Distribution of Pleuroncodes monodon larvae over the continental shelf of south-central Chile: field and modeling evidence for partial local retention 
and transport. Prog. Oceanogr. 92-95, 206-227. doi: 10.1016/j.pocean.2011.07. 005

Conflict of Interest: The authors declare that the research was conducted in the absence of any commercial or financial relationships that could be construed as a potential conflict of interest.

Publisher's Note: All claims expressed in this article are solely those of the authors and do not necessarily represent those of their affiliated organizations, or those of the publisher, the editors and the reviewers. Any product that may be evaluated in this article, or claim that may be made by its manufacturer, is not guaranteed or endorsed by the publisher.

Copyright (C) 2021 Silva and Araújo. This is an open-access article distributed under the terms of the Creative Commons Attribution License (CC BY). The use, distribution or reproduction in other forums is permitted, provided the original author(s) and the copyright owner(s) are credited and that the original publication in this journal is cited, in accordance with accepted academic practice. No use, distribution or reproduction is permitted which does not comply with these terms. 